\title{
IT FOR INFORMATION-BASED PARTNERSHIPS: EMPIRICAL ANALYSIS OF ENVIRONMENTAL CONTINGENCIES TO VALUE CO-CREATION
}

\author{
by \\ Terence J. Saldanha * \\ University of Michigan \\ Nigel P. Melville* \\ University of Michigan \\ Ronald Ramirez * \\ University of Colorado \\ and \\ Vernon J. Richardson * \\ University of Arkansas
}

CES 09-42 December, 2009

The research program of the Center for Economic Studies (CES) produces a wide range of economic analyses to improve the statistical programs of the U.S. Census Bureau. Many of these analyses take the form of CES research papers. The papers have not undergone the review accorded Census Bureau publications and no endorsement should be inferred. Any opinions and conclusions expressed herein are those of the author(s) and do not necessarily represent the views of the U.S. Census Bureau. All results have been reviewed to ensure that no confidential information is disclosed. Republication in whole or part must be cleared with the authors.

To obtain information about the series, see www.ces.census.gov or contact Cheryl Grim, Editor, Discussion Papers, U.S. Census Bureau, Center for Economic Studies 2K130B, 4600 Silver Hill Road, Washington, DC 20233, Cheryl.Ann.Grim@census.gov. 


\begin{abstract}
We empirically examine IT value co-creation in supply chains, incorporating key contingencies of the competitive environment. Prior research suggests that IT used for strategic informationbased partnerships may benefit supply chains facing higher volatility, enabling tightly coupled integration and enhanced strategic response to changing consumer preferences. Analyzing a unique dataset comprising over 6,000 U.S. manufacturing plants, we obtain three principal results. First, value co-creation using either IT for strategic information-based partnerships (ITIP) or merely IT for transaction efficiency (ITT) is positive and significant. Second, the co-created value from ITIP is larger than that for (ITT), suggesting that information-based partnerships, while perhaps requiring a greater investment, yield a higher return. Third and most importantly, co-created value from using IT for information-based partnerships is positively moderated by demand volatility, i.e., value is greater in higher demand volatility environments. However, we find the opposite is true for using IT for efficient transactions. This is a new contribution to the literature and has important theoretical and practical implications.
\end{abstract}

Keywords: Supply Chain Management, Supply chain Partnership, Information Sharing, Environmental Turbulence, Dynamic Capabilities, Agility

* We thank the U.S. Census Bureau, Clint Carter, Margaret Levenstein, Arnold Reznek, Cheryl Grim and staff at the Michigan Census Research Data Center (and other Census Data Centers) for access to the datasets and their untiring support. Support for this research at the Michigan RDC from NSF (ITR-0427889) is also gratefully acknowledged. We are grateful to all participants for their inputs at the 2009 Joint U.S.-Canadian Census Research Data Center Conference held at the Cornell Institute for Social and Economic Research, Ithaca, NY where an earlier version of this paper was presented as a poster. We also thank Dennis Severance and all participants at the BIT Seminar Series at the Ross School of Business for their useful inputs on preliminary versions and presentations based on earlier drafts of this article. Any errors, inaccuracies, oversights and omissions in this article are our responsibility alone. Any opinions and conclusions expressed herein are those of the authors and do not necessarily represent the views of the U.S. Census Bureau. All results have been reviewed to ensure that no confidential information is disclosed. 


\section{INTRODUCTION}

Information technology (IT) has fueled the transformation of supply chains. The scope of strategic options has expanded from transaction oriented arms-length relationships to strategic, long-term partnerships. Interactions that once focused on the transaction efficiency of an individual plant (in the supply chain) can now incorporate process improvement across the entire supply chain to improve productivity and resource efficiency. Interfirm relationships generate joint or co-created value for supply chain partners (Kohli and Grover 2008, Straub et al. 2004) by enabling information transparency, lowering barriers to bi-directional information flow across organizational boundaries (Zhu 2004b), facilitating efficient coordination and integration of processes (Bharadwaj et al. 2007, Lee et al. 2004, Dehning et al. 2007), and enabling coordinated strategic planning across supply chains (Subramani 2004).

A key benefit of interfirm supply chain partnerships enabled by IT is the ability to adapt supply chain processes to match the competitive environment. In doing so, firms can enable agile supply chains (Saraf et al. 2007). Heineken USA, for example, to better respond to changing consumer preferences, introduced a collaborative forecasting and replenishment system to strengthen distribution processes in its supply chain. The system helps tighten linkages between Heineken, and its distributor and retail partners, providing the capability to better match finishedgoods product supply with variations in seasonal and regional demand (Thomas 1997). Proctor \& Gamble (P\&G), a consumer goods manufacturer, created a "consumer driven supply chain network" using information technologies to integrate supply chain partners and allow $P \& G$ to meet consumer demand requirements. The network uses aggregate point-of-sale scanner data from key accounts to run manufacturing plants at a 6-8 hour replenishment response time. The 
network also integrates $P \& G$ with upstream supply partners via a web portal, sharing consumer demand data and real-time production plans with critical partners (SupplyChainBrain 2006).

Demand volatility is a particularly important area of study due to the challenges it presents to firms. Demand volatility can degrade customer service levels, reduce product revenues (Waller et al. 1999), increase the risks associated with over and under production capacity in manufacturers (Tan 2002), and result in a bullwhip effect where demand variability is amplified as it moves up the supply chain (Lee et al. 2004). Firms employ information technologies to mitigate the negative impacts of demand volatility. When volatility is high, firms utilize the online channel as an efficient means for interacting with customers (Kiang and Raghu 2000). Firms such as Cisco utilize e-hubs to track inventory and order status of downstream suppliers (Lee et al. 2004). Tightly coupled supply chain relationships enable a high degree of information sharing about raw material and production, and mitigate demand uncertainties when vendors manage the inventory of downstream customers (Waller et al. 1999).

Intuitive considerations thus suggest that supply chains facing higher demand volatility would benefit from tightly coupled integration. In such situations, using IT to enable strategic information-based partnerships may be more beneficial than using IT for transaction efficiency. However, despite the conceptual and intuitive basis for environmental contingencies to value cocreation in supply chains - as well as the practical implications - we could not identify any prior studies that examined this phenomenon. Our research question is thus: "To what extent is IT value co-creation in supply chains contingent on the competitive environment?"

Analysis of our research question necessitates a large dataset comprising manufacturing plants engaged in alternative forms of IT value co-creation so that we can capture sufficient variation in demand volatility. We have access to a unique, cross-sectional time-series dataset 
that fits these criteria: the U.S. Census Bureau's Computer Network Use Survey. Estimation of panel econometric models including the Hausman-Taylor model yield the following three principal results. First, plants engaged in both types of IT-value co-creation - IT used for strategic information-based partnerships (ITIP) and IT used for transaction efficiency (ITT) receive a positive and significant return on their investment. Second, the co-created value from ITIP is larger than that for ITT. Third and most importantly, co-created value from ITIP is positively moderated by demand volatility, but the opposite is true for ITT. This last result is consistent with our primary thesis and suggests that in high-volatility conditions, supply chains are better off pursuing tightly coupled integration enabled by using IT for strategic informationbased partnerships (ITIP) rather than loosely coupled integration enabled by investing in information technology for transaction efficiency (ITT). This is a new result to the literature and has important theoretical and practical implications. In sum, our paper contributes to the Information Systems (IS) literature by shedding new light on how IT value co-creation in supply chains is contingent on the competitive environment.

The remainder of this paper is organized as follows. In Section 2 we review related literature. Theoretical background and hypotheses are presented in Section 3. Section 4 describes the research design and methodology. In Section 5 we present results of our empirical analysis. In Section 6 we discuss the implications and limitations of this study and how these limitations might be overcome in future research.

\section{LITERATURE REVIEW}

We define co-created value as the economic rents generated within an interfirm relationship by a unique combination of complementary relation-specific resources that partnering firms bring to bear (Dyer and Singh 1998). Specifically, we focus on information 
sharing across partner firms as a key dimension of complementary relation-specific resources in the supply chain. Given our focus, two streams of literature are relevant: 1) information sharing in the supply chain, 2) role of IT-enabled information sharing under volatile demand conditions.

\subsection{Co-creation of Value via Information Sharing in the Supply Chain}

In the context of supply chains, the value of IT is often focused on e-business transactions and their impact on sales and internal operations (Zhu and Kraemer 2005, Amit and Zott 2001, Zhu 2004a). Though IT for transactions is an enabler of performance, the mere use of technology is not a robust indicator of collaboration for co-creation of value as collaboration in the supply chain is not synonymous with e-business technology use (Sanders 2007). Information sharing represents a higher level of strategic partnership in the supply chain (Sabath and Fontanella 2002).

The role of information sharing in the supply chain is a topic of great managerial importance and has been a focus of much research in the information systems and operations management literatures (Sahin and Robinson 2002, Cachon and Fisher 2000, Mukhopadhyay et al. 1995, Clemons and Row 1993, Barua et al. 2004). Information is widely recognized as an important driver of supply chain performance by enabling firms to substitute inventory for information (Milgrom and Roberts 1988). The types of information shared typically include information related to inventory, sales, order status, sales forecast and production schedules (Lee and Whang 2000). Cachon and Fisher (2000) modeled information sharing in the supply chain and found that information sharing reduces supply chain costs. At the plant level, Mukhopadhyay et al. (1995) found that information exchanges between Chrysler plants and their suppliers resulted in significant operational benefits for Chrysler through improved inventory management and labor savings. 
Efficiency gains through information exchanges may be even more pronounced in the current era of open Internet standards. As noted by Frohlich and Westbrook (2001), the Internet makes it "easier to broaden the types of information being exchanged across supply chain entities". Examining partnerships as a unit of analysis, Malhotra et al. (2007) find that the use of standard electronic business interchanges was associated with higher adaptation and knowledge creation in the supply chain and this effect was mediated through information exchange.

However, despite prior research that has informed understanding of the role of information sharing in supply chains, we could not identify any quantitative empirical studies that examine IT as an enabler of co-created value employing objective measures of information sharing and financial value.

\subsection{Environmental Contingencies of Co-created Value}

\section{Demand Volatility}

Demand volatility is a major contributor to overall environmental uncertainty and has been identified as an important factor influencing supply chain design (Fine 2000, Germain et al. 2008). Demand volatility can have many negative effects on firms, degrading customer service levels, reducing product revenues and overall financial performance (Waller et al. 1999, Germain et al. 2008, Gattorna 1998). Many of these effects occur due to the distortion in production information that occurs as demand data is passed upward in the supply chain. In the end, the volatility leads to a bullwhip effect as firms build safety stocks to buffer the wide variations in customer demand that occur due to economic shocks, promotions, and other factors influencing product purchases (Lee et al. 2004). 


\section{Mitigating Negative Effects of Demand Volatility}

Analytic studies related to the value created through information sharing partnerships under varying demand conditions yield mixed conclusions. Cachon and Fisher (2000) showed that there is an upper bound on the value of information sharing within the context of a stationary demand supply chain - accelerating the physical flow of goods through a supply chain is significantly more valuable than expanding the flow of information. Raghunathan (2001) found that information sharing is of limited value when the parameters of the non-stationary demand process are known to both parties because manufacturers can reasonably forecast demand without the information given by the retailer. Gosain et al. (2005) examined supply chain partnerships and found that the breadth of information sharing was negatively associated with partnering and supply chain flexibility. The authors use survey-based measures of flexibility of linkages between firms and operationalize flexibility as the ability of the organization to phase out new products, respond to change and replace their business partner with a new partner.

While demand volatility, lead time, production capability and cost are likely to be the major factors affecting the value of information-based partnerships, these factors have different influences on the value of information sharing ( $\mathrm{Li}$ et al. 2005). Lee et al. (2000) posits that the larger the demand variance, the larger value of information sharing whereas Chen (1998) finds that the value of information sharing is mitigated in a volatile environment. Other analytical models have found the value of information sharing to be higher when there is less variance in demand (Schouten et al. 1994, Gavirneni et al. 1999) or when demand is more correlated across time periods (Ragunathan 2003). In an experimental study, Steckel et al. (2004) concluded that sharing end-customer sales data was harming the supply chain performance, when demand was assumed to be changing continuously. In that situation, the sales data were distracting the 
distributor from other information. Moreover, reducing lead times was highly beneficial for decision making in the experiment. A similar result was obtained by Treville et al. (2004), who state that the benefits from lead time reduction are greater than the benefits from capturing demand data.

Related to information sharing, IS research has examined how turbulent conditions may impact the value from IT. For instance, the marginal product of IT capital at the firm level has been found to be higher in more dynamic environment conditions (Melville et al. 2007). In the context of new product development, it has been found that environmental turbulence negatively affects the impact of IT functional competencies on competitive advantage (Pavlou and Sawy 2006).

In sum, review of the literature indicates that most studies in the area of information sharing in the supply chain employ analytic modeling (e.g. Cachon and Lariviere 2001, Cachon and Fisher 2000) or simulation (Steckel et al. 2004, Boone et al. 2002). To our knowledge, there are limited empirical studies on the co-creation of value through information sharing and we could not identify any that analyze how IT value co-created in supply chains is contingent on the competitive environment. As noted by Rai et al. (2006, pg. 226), "empirical research related to the digitally integrated supply chain integration phenomenon has been limited and piecemeal". Our study is a step towards addressing this gap in the literature.

\section{THEORY AND HYPOTHESIS DEVELOPMENT}

Our conceptual model is presented in Figure 1. We posit that co-created value occurs when a partnership is established between two firms. The objective of the partnership can range from the simple automation of inter-organizational transactions to the strategic integration of key inter-organization processes. The link between the firms is enabled through investments in 
information technology and other capital and labor inputs. The implementation of the partnership generates co-created value as a whole with each firm experiencing a net value impact. The value created through partnerships is moderated by numerous environmental and market factors such as economic recessions, disruptive innovations, and the like. In this study, we focus on information technology and its relationship to partnership value, while also examining the moderating impact of demand volatility. We now explicate our baseline and core hypotheses.

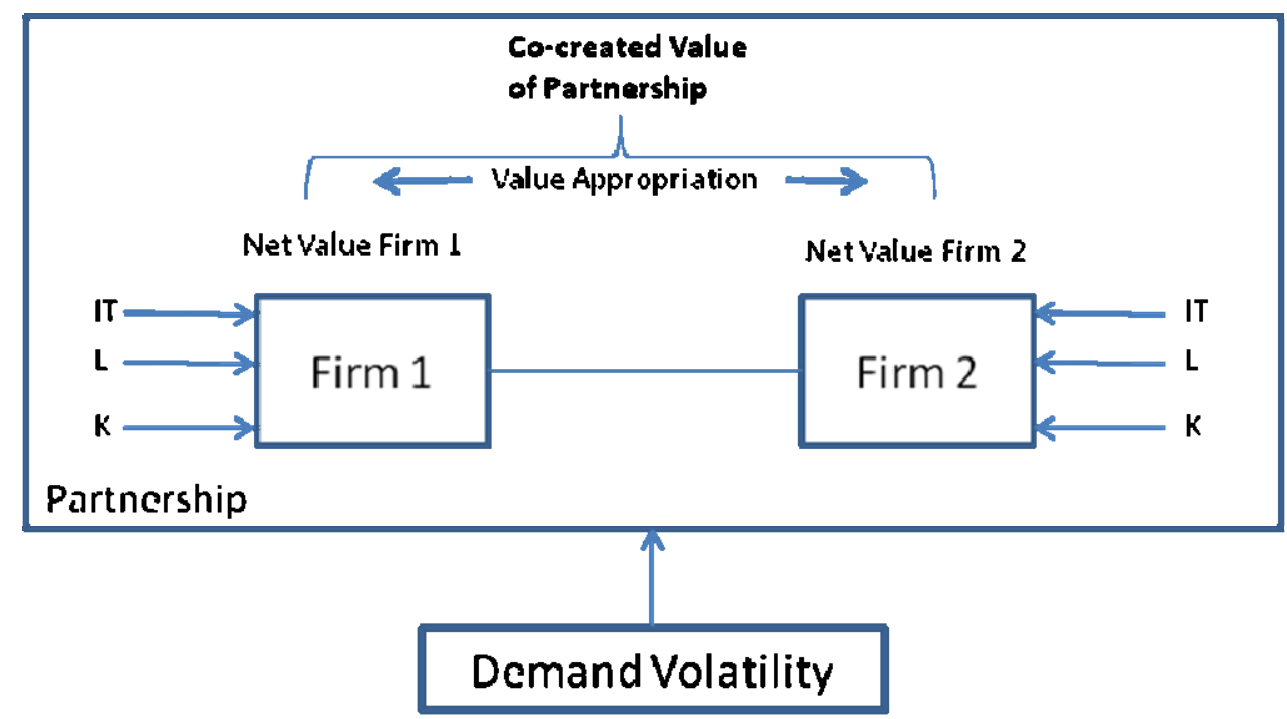

Figure 1: Conceptual Model

\subsection{Baseline Hypotheses of Value Co-Creation}

\section{IT for Transactions (ITT)}

Information technology used for transactions targets the automation of structured and routine processes. Such applications utilize IT as a substitute for repetitive human effort, improving the timeliness of each transaction and reducing associated errors (Zuboff 1988). In an interorganizatoinal setting, these types of technologies help reduce the costs of transactions between the buying and selling firms (Gurbaxani and Whang 1991), as well as associated operational costs within each participate organization (e.g., shipping costs, Srinivasan et al. 
1994). Indeed, empirical work examining the use of technologies like electronic data interchange (EDI) in manufacturers has demonstrated a contribution to firm savings, in for instance, the purchasing of maintenance, repair, and operations (MRO) and raw product parts (Mukhopadhyay et al. 1995). Dehning et al. (2007) find that IT-based supply chain systems increase gross margin, inventory turnover (particularly raw materials and finished goods inventory turnover), market share, return on sales, and reduce selling, general, and administrative expenses. Web based procurement can even go further in performance improvement by helping to reduce search related costs in purchasing activities (Subramaniam and Shaw 2002) as well as improve sales and internal operational efficiencies (Zhu and Kraemer 2005, Zhu 2004a). Indeed, companies that use e-procurement technologies (e.g., software, auctions, market exchanges) have reported a savings of $42 \%$ in purchasing performance (Davila et al. 2002). We thus hypothesize:

H1a: (ITT Value Co-creation) The use of IT for transactions with partner firms is positively associated with value (as measured by labor productivity)

H1b: (ITT Value Co-creation) The use of IT for transactions with partner firms is positively associated with value (as measured by inventory turnover)

\section{IT for Information-based Partnerships (ITIP)}

There is an emerging general consensus that sharing information leads to benefits for supply chain members and forms the core foundation on which supply chain collaboration is based (Lee and Whang 2000). Information-based partnerships enable the supply chain to informate and transform key business processes (Zuboff 1988). Information sharing also provides the ability to improve forecasts and coordinate inventory and production decisions through a shared understanding of performance issues (Rai et al. 2006). We thus hypothesize:

H2a: (ITIP Value Co-creation) The use of IT in information-based partnerships is positively associated with value (as measured by labor productivity) 
H2b: (ITIP Value Co-creation) The use of IT in information-based partnerships is positively associated with value (as measured by inventory turnover)

\subsection{Contingent Role of the Environment on IT Value Co-Creation}

The Resource-Based View (Barney 1991) of the firm posits that resources that are valuable, rare, inimitable and non-substitutable yield competitive advantages. The value of resources, however, depends on their environment and can change rapidly as the environment evolves (Katila and Shane 2005, Miller and Shamsie 1996). In the case of IT resources, the value of resources must be viewed in conjunction with the environment (Melville et al. 2004). The guiding theory behind our arguments is that IT resources are non-homogenous (Weill 1992). According to the classification by Weill (1992), 'transactional IT' (ITT) comprises those IT investments that are made to automate the firm's business processes. 'Informational IT' (ITIP) provides the information infrastructure to enable tasks such as control, budgeting, planning, and analysis (Weill 1992). Their model's central tenet of IT as a non-homogeneous construct has often been used to explain mixed research findings on the impact of IT investments (Lind and Zmud 1995). We draw on this theoretical framework to explicate how value co-created by partnering organizations using the non-homogenous components of IT in the supply chain can be differently impacted by environmental dynamism. In other words, in turbulent environments, different IT capabilities are required for superior performance than in stable environments (Eisenhardt and Martin 2000, Wade and Hulland 2004).

As our review of the literature suggests, co-created value via information-based integrated partnerships in the presence of turbulent demand conditions has yet to be analyzed empirically. It is possible that in a changing, volatile environment, information shared may be inaccurate, unavailable or obsolete (Bourgeois and Eisenhardt 1988). By extension of this argument, a firm's efforts to co-create value with its partners by engaging in information-based partnerships may be 
adversely affected by turbulent environments. Some prior research employing analytic modeling suggest that in situations of larger demand variance, the value of information sharing may be limited (Chen 1998).

In contrast, we argue that information-based partnerships can provide the firm with more information to mitigate negative impacts of changing volatile conditions. This line of argument draws from the theory of dynamic capabilities (Eisenhardt and Martin 2000, Teece et al. 1997) by which information-based partnerships through IT can help the firm reconfigure its resources in the face of changing business environments (Gosain et al. 2005). We build on the literature which analytically models information sharing and suggests that information sharing across the supply chain is more valuable when parameters of demand process are unknown (Raghunathan 2001) or when there is high demand volatility (Bourland et al. 1996, Lee et al. 2000).

In more volatile environments, integrated partnerships through IT can potentially provide new information to managers and improve co-ordination through reduction of uncertainty (Clemons and Row 1993). For example, through the sharing of inventory information and order information electronically with its component suppliers, Cisco has developed an agile supply chain to cope with changing demand (Dong et al. 2009). The information-based partnerships between Cisco and its suppliers and customers significantly improve Cisco's ability to rapidly respond to the demand changes in the supply chain. Additionally, by sharing information with their suppliers and customers, firms such as Dell and Whirlpool are able to better match supply closely to customer demand and to anticipate changes in the marketplace (Li et al. 2006). As another example, Herlitz, a Europe-based manufacturer of office supplies, used J.D. Edwards Planning Solution to share real-time information with customers and suppliers and to analyze customer demand fluctuations, thereby achieving lower inventory levels (Business Week 2009). 
The collaboration between firms based on integrated partnerships can help the supply chain respond to changes in end-customer demand through improved scheduling and inventory management techniques (Kulp et al. 2004). For example, integrated information-based partnerships with suppliers can help the firm plan production schedules with greater flexibility in manufacturing changeovers so as to adjust to frequent changes in customer demand (Setia et al. 2008) and build an agile supply chain by using real-time information. Thus information-based integrated partnerships enabled by IT provide business agility in environments with "higher clockspeeds" (Setia et al. 2008, pg 18).

In sum, ITIP can play an important role in supporting the growth of the flexible value network of a firm enabling them to transfer real-time information to operate in a high-clockspeed environment (Dedrick and Kraemer 2005). The strategic use of IT to share rich information across organizational boundaries can help managers overcome problems caused by demand volatility (Daft and Lengel 1986, Moenart and Souder 1996), reduce information asymmetry and mitigate the negative effects of variability in demand. Conversely, in stable environments, when information such as demand projections is shared, it may not provide new information and hence is of lesser incremental value in facilitating rapid decision making (Lee et al. 2000, Melville et al. 2007). Based on these arguments, we hypothesize that the ability of firms to co-create value in the supply chain through information-based partnerships will be reinforced in more volatile demand environments. We thus hypothesize the following:

H3a: The positive association between IT for information-based partnerships and cocreated value (as measured by labor productivity) is positively moderated (reinforced) by volatile demand conditions.

H3b: The positive association between IT for information-based partnerships and cocreated value (as measured by inventory turnover) is positively moderated (reinforced) by volatile demand conditions. 
We posit that IT for Transactions (ITT) is a first stage in the integration for co-creation of value. Its focus is on automation of the transaction process and improvement of efficiency. The transition from transactional IT to collaborative IT requires levels of trust and commitment that are beyond those typically found in transactional IT relationships. For instance, firms can use IT for EDI and JIT (Just-In-Time) without achieving the next level of integration where design and long-term strategic data are shared (Spekman et al. 1998). In a supply chain context, Dong et al. (2009) argues that the value of commodity-like IT resources that "do not meet the RBV criteria" diminishes under competition.

We extend this argument to posit that IT for Transactions (ITT) is an example of commodity-like resource and that it will be less valuable in highly volatile environments. ITT can allow for integration of transactions but not other elements (such as strategic planning) required to tide over volatile demand conditions. Transactional technology implementations are thus inside-out in nature and their value is likely to be stronger in stable business environments rather than in turbulent business environments (Wade and Hulland 2004). Since ITT typically does not involve cross-organizational long term planning (Spekman et al. 1998), changes in market demand can have detrimental effects on the co-created value of IT when used for purely transactional purposes. For example, orders are the result of "conjectures by the buyer" and can "distort the true dynamics of the marketplace" (Lee and Whang 2000, pg. 4) and exacerbate the bullwhip effect as demand variability is amplified and moves up the supply chain (Lee et al. 2004). Additionally, although the use of ITT may improve the efficiency of organizations, it is less likely to enable the focal firm to build strategic partnerships with trading partners (Crowe 1992). While ITT helps performance by improving accuracy, eliminating paperwork and reducing costs, it has negligible impact on supply chain planning and scheduling and so does 
little to help reduce the uncertainty faced by trading partners in determining future demand. Hence we hypothesize that the ability of ITT to co-create value through increased productivity and lower inventory will be mitigated under highly volatile demand conditions. This leads to our fourth hypothesis,

H4a: The positive association between IT for Transactions and co-created value (as measured by labor productivity) is negatively moderated (attenuated) by volatile demand conditions.

H4b: The positive association between IT for Transactions and co-created value (as measured by inventory turnover) is negatively moderated (attenuated) by volatile demand conditions.

\section{RESEARCH METHODOLOGY}

\subsection{Data}

Data for this study were drawn from multiple U.S. Census Bureau surveys. The Computer Network Use Supplement (CNUS) dataset provided data related to information technology usage and information sharing. The CNUS survey was conducted by the Census as a supplement to the 1999 Annual Survey of Manufacturers (ASM) and relates to electronic business practices adopted by establishments. The performance variables are drawn from the Annual Survey of Manufacturers (ASM) and Census of Manufacturers (CM) while control variables were drawn from the ASM, CM and Survey of Plant Capacity Utilization (SPCU).

An important consideration in the construction of our panel dataset concerns the availability of data across years. Whereas the ASM, CM and SPCU are annual surveys, the CNUS was a one-time survey. In the CNUS survey, each establishment was asked about its current use of computer-networked business processes as well as its planned use of these processes by 2002. In the interest of using as much data as possible, we constructed a panel dataset for the years 1997 to 2002 by coding plants that reported usage of a technology in the 
CNUS as also using that technology in 1997. Further, we coded plants that reported plans to use technologies by 2002, as actually using that technology in 2002 first. These, we believe, are reasonable assumptions given that e-business technologies and their implementations are important IT investments that require considerable planning ${ }^{1}$. For ITIP measures, only current use was asked and therefore, ITIP is time-invariant in our data. The compromise between having a large enough number of years of data to account for plant-level heterogeneity as well as small enough to ensure constancy of practices (independent variables) which are measured one-time has been made in prior research (Black and Lynch 2001, Brynjolfsson et al. 2007). Table 1 shows the data which are available and those that are imputed in our dataset.

\begin{tabular}{|l|c|c|c|c|c|c|}
\hline \multirow{2}{*}{\multicolumn{7}{|c|}{ Table 1: Data Sources }} \\
\cline { 2 - 7 } & $\mathbf{1 9 9 7}$ & $\mathbf{1 9 9 8}$ & $\mathbf{1 9 9 9}$ & $\mathbf{2 0 0 0}$ & $\mathbf{2 0 0 1}$ & 2002 \\
\hline Total Value of Shipments & $\mathrm{CM}$ & ASM & ASM & ASM & ASM & CM \\
\hline Total Inventory & CM & ASM & ASM & ASM & ASM & CM \\
\hline IT for Transactions(/TT) & CNUS99 & CNUS99 & CNUS & CNUS99 & CNUS99 & CNUS \\
\hline $\begin{array}{l}\text { IT for Information-based } \\
\text { Partnership (/T/P) }\end{array}$ & CNUS99 & CNUS99 & CNUS & CNUS99 & CNUS99 & CNUS99 \\
\hline Labor & CM & ASM & ASM & ASM & ASM & CM \\
\hline Materials & CM & ASM & ASM & ASM & ASM & CM \\
\hline Energy & CM & ASM & ASM & ASM & ASM & CM \\
\hline Capital & CM & i & i & i & i & CM \\
\hline Capacity Utilization & SPCU & SPCU & SPCU & SPCU & SPCU & SPCU \\
\hline Skill Mix & CM & ASM & ASM & ASM & ASM & CM \\
\hline Share of Exports & CM & ASM & ASM & ASM & ASM & CM \\
\hline $\begin{array}{l}\text { ASM: Annual Survey of Manufacturers, CNUS: Computer Network Use Supplement. } \\
\text { SPCU: Survey of Plant Capacity Utilization, CM: Census of Manufacturers } \\
\text { i: Imputed using Perpetual Inventory Management System (PIMS) methodology }\end{array}$ \\
\hline
\end{tabular}

\subsection{Variable Definitions}

\section{Dependent Variables}

Our dependent variables, though intended to capture the value from co-creation of interorganizational IT partnerships, are measures within the focal plant. Though we would have

\footnotetext{
${ }^{1}$ We also repeated the analysis using a shorter panel (1999-2002) which made less restrictive assumptions of usage prior to reporting and found coefficient estimates that are consistent with those presented here, although as expected, the statistical precision declines along with sample size.
} 
ideally liked to capture the value also at the inter-organizational level, our current dataset does not permit such a measurement. We however expect there to be a strong correlation between the dependent variable measures we adopt and value created at the partnership level. We use labor productivity (Melville et al. 2007) as our primary performance measure and also test our conceptual model using inventory turnover (Bharadwaj et al. 2007, David et al. 2002) as a performance measure. Both these measures of performance are commonly used in IT value and operational performance research. Plant-level labor productivity is defined as gross output per worker $(\mathrm{Q} / \mathrm{L})$. We use total value of shipments as a measure of gross output $\mathrm{Q}$ (Atrostic and Nguyen 2005). Our measure of labor, L, is the total number of employees in the plant. Inventory is defined as the sum total of raw-material inventory, work-in-process inventory and finishedgoods inventory as a percentage of sales. When the analysis was repeated using only rawmaterials and finished-goods inventory as a percentage of sales, the results remain qualitatively unchanged.

\section{Independent Variables}

The measures of 'IT for Transactions' and 'IT for Information-based Partnerships' are count-based composite measures. Count-based measures have been used in prior IT and Supply Chain research (Doms et al. 1997, Kulp et al. 2004, Banker et al. 2006). We count the reported number of transactional IT measures (ITT) and information sharing (ITIP) measures used by the plant as reported in the CNUS. As described earlier, a panel is constructed for the period 19972002. Volatility in demand is measured as the standard deviation of (the log of) plant output (total value of shipments) over the previous five years (Bansak et al. 2007). This is consistent with the research literature in this area where volatility is usually quoted as an "annualized percentage standard deviation" (Dewan et al. 2007, Kobelsky et al. 2008). To test the robustness 
of the results, we used multiple other alternate measures of volatility. First, qualitatively similar results were obtained when the analysis was performed using standard deviation of the change in (log) demand as the measure of volatility. Second, we calculated volatility measured over 3 years and found similar results. Third, we used standard deviation of $(\log )$ Value-Added over previous five years as a measure of volatility. Finally, we used a binary measure of volatility (HIGHVOLATILITY which is 1 for plants with volatility above the median and 0 otherwise). In all these robustness checks, we found the results to be largely substantively consistent with those shown here.

The ITT and ITIP indices are, intuitively, formative because use of any particular measure of ITT or ITIP does not necessarily imply use of every measure forming the index. For example, a plant may share information on some areas but not all areas (Gosain et al. 2005), and so a formative construct is more appropriate. Since the index is formative, it need not be subject to the usual tests of internal consistency of reflective constructs (Diamantopoulos and Winklhofer 2001) and its indicators are not required to co-vary with each other (Jarvis et al. 2003).

\section{Control Variables}

We used a comprehensive set of control variables. The control variables include plantspecific factors which have been found to affect productivity and inventory in prior work. These controls include material intensity, capital intensity, energy intensity, capacity utilization, share of exports (Wagner 2002), age of the plant (Dunne 1994) and skill mix of (non-production to production) workers (Berman et al.1994). Plant age can have a dual effect on productivity. New plants enter with higher productivity (due to newer technology) than earlier entrants did, whereas surviving plants show productivity increases as they age (Jensen et al. 2001). We also control for 
size of plant (Lucas 1978), industry (at the 3-digit NAICS level), and whether or not the plant is part of a multi-plant firm. We follow previous studies (Atrostic and Nguyen 2005, McGuckin and Stiroh 1998, Greenan and Mairesse 2001) and use book values of the capital as a proxy for capital. We used the standard Perpetual Inventory Management Method (Bansak et al. 2007, Black and Lynch 2001) to compute capital ${ }^{2}$ for the years in which capital was unavailable. ${ }^{3}$ A more detailed description of the computation of the variables is provided in Appendix C.

\subsection{Empirical Modeling}

Our conceptual model appears in Figure 2 below. We use our developed panel dataset to estimate various econometric model specifications using two measures of performance as our dependent variables - labor productivity and inventory.

\section{Productivity Model}

The dependent variable in this model is labor productivity $(L L P)$ for the plant measured as 'Total value of shipments per employee' ${ }^{4}$ We use the gross output specification (McGuckin and Nguyen 1995, Atrostic and Nguyen 2005) though using the value-added specification gave us qualitatively similar results. In accordance with prior research, we control for capital intensity, material intensity, energy intensity, plant size, capacity utilization, plant age, skill mix, whether the plant is part of a multi-plant firm, industry dummy controls at the 3-digit NAICS level and

\footnotetext{
2 For example, $\mathrm{K}$ at end of $2000=\mathrm{K}$ at beginning of $2001=\mathrm{K}$ at end of $2001-$ (Total Capital Expenditures in 2000 - Retirements). Total capital expenditure in 2000 is available in the 2000 ASM. As retirements in 2000 are not available, we compute $\mathrm{K}$ at end of 2000 by the above formula using retirements in 2002 rolled backward. This is a reasonable approximation, as retirements exhibit less variability due to accounting rules than do new capital expenditures. An alternative method of constructing capital is to roll expenditures forward in a perpetual inventory method, which gave qualitatively similar results.

${ }^{3}$ Moreover, the correlation between capital values based on perpetual-inventory method and the book-value series has been found to be above .90 (Luque 2002, Doms 1996). Therefore, since physical capital is not available for all years in our sample, the values we use based on the PIMS method should be a reasonable proxy for the physical capital stock.

4 When the analysis was performed the a na lysis using (log of) total value of shipments as the dependent variable with gross va lues of c a pital, ma teria ls and energy as controls, results were unchanged.
} 
time (year) dummies. In the productivity model, $\mathrm{H3a}(\mathrm{H} 4 \mathrm{a})$ hypothesizes a positive (negative) sign on $\beta_{4}\left(\beta_{5}\right)$. Tests of the hypotheses related to labor productivity are conducted by estimating the following regression model (Model 1):

$$
L L P_{\mathrm{it}}=\beta_{0}+\beta_{1} I T T_{\mathrm{it}}+\beta_{2} I T I P_{\mathrm{i}}+\beta_{3} \text { Volatility }_{\mathrm{it}}+\beta_{4}\left(\text { ITIP x } \text { Volatility }_{\mathrm{it}}+\beta_{5}(\text { ITT x Volatility })_{\mathrm{it}}+\right.
$$

$\beta_{\mathrm{c}} \mathbf{X} \mathbf{c}_{\mathrm{it}}+\varepsilon_{\mathrm{it}}$, where $\mathbf{X} \mathbf{c}$ is the vector of control variables.

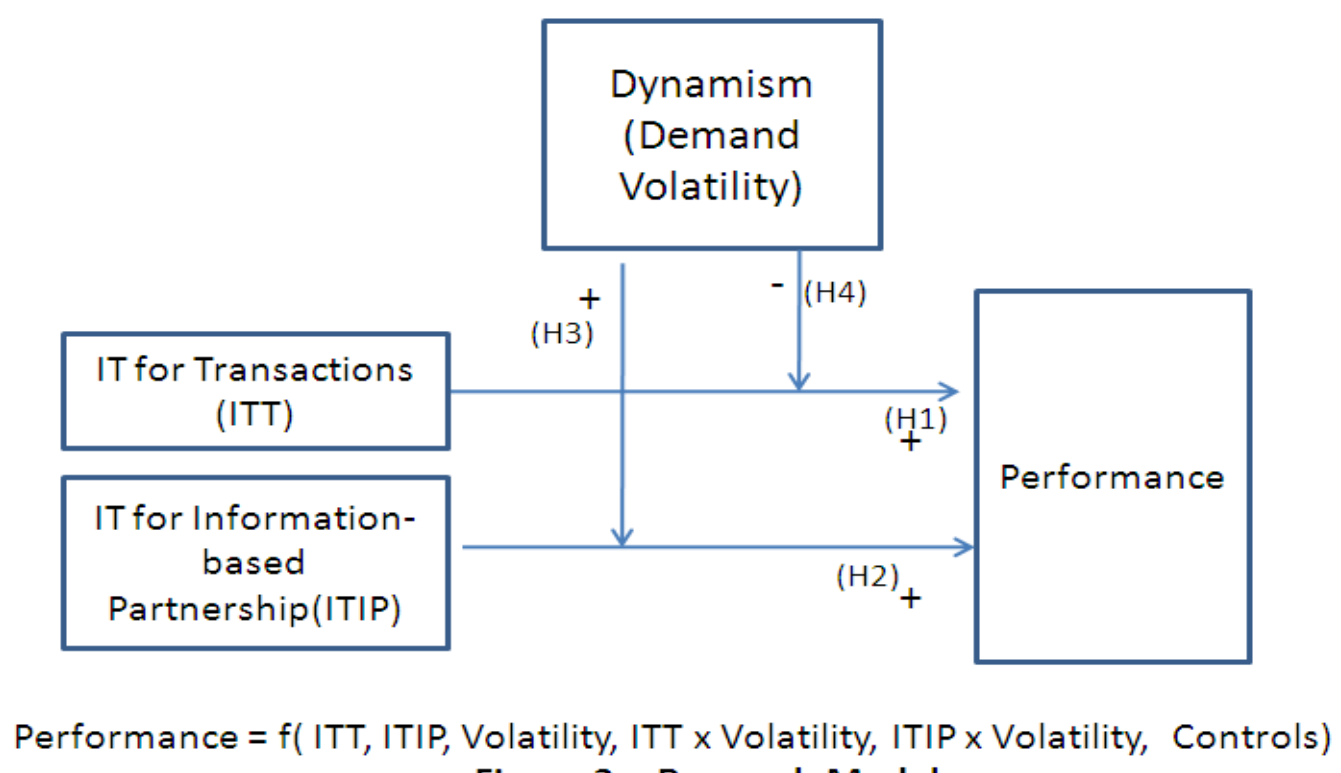

Figure 2: Research Model

\section{Inventory Model}

The dependent variable in this model is $I N V$, which is calculated as the $(\log )$ ratio of total inventory to sales for the plant. In line with prior research, we control for plant size, capacity utilization, capital-labor ratio, whether the plant is part of a multi-plant firm, industry dummy controls at the 3-digit NAICS level and time (year) dummies. It is to be noted that since the dependent variable is expressed as the ratio of inventory to sales, $\mathrm{H} 3 \mathrm{~b}(\mathrm{H} 4 \mathrm{~b})$ hypothesizes a negative (positive) sign on $\beta_{4}\left(\beta_{5}\right)$. Tests of the hypotheses related to inventory are conducted by estimating the following regression model (Model 2):

$I N V_{\mathrm{it}}=\beta_{0}+\beta_{1} I T T_{\mathrm{it}}+\beta_{2} \operatorname{ITIP}_{\mathrm{i}}+\beta_{3}$ Volatility $_{\mathrm{it}}+\beta_{4}(\text { ITIP x Volatility })_{\mathrm{it}}+\beta_{5}(\text { ITT x Volatility })_{\mathrm{it}}+$ $\beta_{\mathrm{c}} \mathbf{X c}_{\mathrm{it}}+\varepsilon_{\mathrm{it}}$, where $\mathbf{X} \mathbf{c}$ is the vector of control variables. 


\subsection{Sample Description}

After merging the ASM, CM, SPCU and CNUS datasets, the final sample consists of 6,185 plants (19,023 plant-year observations) for the Productivity model and 6,506 plants (21,204 plant-year observations) for the Inventory model. The descriptive statistics and correlations for the Productivity model are provided in Table $2^{5}$. Appendix A illustrates how the proportion of plants in our (Productivity model) sample in each industry compares with the population as per the "Statistical Abstract of the United States: 2003" for the year 2000.

\begin{tabular}{|c|c|c|c|c|c|c|c|c|c|c|c|c|c|c|c|c|}
\hline \multicolumn{2}{|r|}{ Variables } & $\mathrm{N}$ & Mean & SD & 1 & 2 & 3 & 4 & 5 & 6 & 7 & 8 & 9 & 10 & 11 & 12 \\
\hline 1 & Labor Productivity & 35580 & 5.52 & 0.79 & 1 & & & & & & & & & & & \\
\hline 2 & ITT & 31608 & 2.96 & 2.43 & 0.00 & 1 & & & & & & & & & & \\
\hline 3 & ITIP & 35580 & 1.86 & 2.29 & $0.04^{*}$ & $0.41^{*}$ & 1 & & & & & & & & & \\
\hline 4 & Volatility & 35495 & 0.16 & 0.17 & $-0.06^{\star}$ & 0.01 & 0.00 & 1 & & & & & & & & \\
\hline 5 & Capital & 35557 & 4.35 & 1.11 & $0.53^{*}$ & $0.06^{*}$ & $-0.02 *$ & -0.01 & 1 & & & & & & & \\
\hline 6 & Material & 35580 & 4.68 & 1.04 & $0.85^{\star}$ & $-0.02^{\star}$ & $-0.04^{*}$ & $-0.05^{\prime}$ & $0.45^{\star}$ & 1 & & & & & & \\
\hline 7 & Energy & 35580 & 0.69 & 1.08 & $0.46^{\star}$ & $-0.03^{*}$ & $-0.12^{\star}$ & $-0.03^{\prime}$ & $0.62^{*}$ & $0.43^{*}$ & 1 & & & & & \\
\hline 8 & Capacity Utilization & 35580 & 0.73 & 0.20 & $0.13^{*}$ & $-0.08^{*}$ & $-0.06^{\star}$ & $-0.13^{\prime}$ & $0.08^{*}$ & $0.13^{*}$ & $0.15^{*}$ & 1 & & & & \\
\hline 9 & Size & 35580 & 5.69 & 1.10 & $-0.07^{*}$ & $0.13^{*}$ & $0.19^{*}$ & $-0.11^{\prime}$ & -0.01 & $-0.07^{\star}$ & $-0.13^{*}$ & $0.15^{*}$ & 1 & & & \\
\hline 10 & MULTIPLANT & 35580 & 0.94 & 0.23 & $0.14^{*}$ & $0.08^{*}$ & $0.01^{*}$ & $0.02^{*}$ & $0.14^{*}$ & $0.13^{*}$ & $0.12^{*}$ & 0.00 & $0.13^{*}$ & 1 & & \\
\hline 11 & Age of Plant & 35580 & 24.9 & 6.92 & $0.04^{*}$ & $0.02^{*}$ & $0.03^{*}$ & $-0.09^{\prime}$ & $0.1^{*}$ & $0.02^{*}$ & $0.09^{*}$ & $0.05^{\star}$ & $0.23^{*}$ & $0.04^{*}$ & 1 & \\
\hline 12 & Share of Exports & 21348 & -2.83 & 1.68 & $-0.08^{*}$ & $0.05^{\star}$ & $0.09^{*}$ & $0.06^{\star}$ & 0.02 & $-0.09^{*}$ & $-0.06^{*}$ & $-0.05^{\star}$ & $0.07^{\star}$ & 0.01 & $-0.03^{*}$ & 1 \\
\hline 13 & Skill Mix & 35175 & -1.49 & 0.70 & $0.07^{*}$ & $0.09^{*}$ & $0.08^{*}$ & $0.06^{*}$ & $0.06^{*}$ & 0.01 & $-0.09^{*}$ & $-0.15^{\star}$ & $-0.07^{*}$ & 0.00 & 0.00 & $0.22^{*}$ \\
\hline
\end{tabular}

\subsection{Estimation Approach and Specification Testing}

In order to allow for individual heterogeneity across manufacturing plants, we estimated the fixed-effects and random-effects models. The Breusch-Pagan Lagrange Multiplier test (Breusch and Pagan 1980) indicated that the random effects are significant and so Ordinary Least Squares on the pooled data would be inappropriate. The random-effects model, however, assumes that there is no correlation between the individual random effects and the covariates (Greene 2003). The Hausman's specification test for the random-effects model rejected the null

5 The descriptive and correlations for the Inventory model are provided in Appendix B. 
thereby indicating that the random-effects estimator is inconsistent whereas the fixed-effects estimator, though inefficient, is consistent (Greene 2003). In view of these empirical considerations, the fixed-effects estimator is considered the most appropriate for our analysis. We used a fixed-effects model with White's correction to account for any heteroskedascticity problems (White 1980). The fixed-effects estimator accounts for features that are unobservable but stable over time and their possible correlation with explanatory variables. Fixed-effects models are considered conservative because only changes in independent variables within a unit can produce significant effects. We included year dummy variables to eliminate year-specific heterogeneity. Thus, our models control for both plant-specific and time-specific effects. We also tested for multicollinearity using Variance Inflation factors which were within acceptable limits (Greene 2003), indicating that multicollinearity was not a serious problem in the data.

Given the unbalanced nature of our sample and the use of fixed-effects models, sample bias was a potential concern. To address this issue and test the robustness of the sample, we followed the method proposed by Wooldridge (2002), who argued that in a fixed-effects model with an unbalanced panel, sample bias is not a problem if the selection is uncorrelated with the idiosyncratic error term of the model. To test this assumption, we re-estimated the models by adding a selection indicator variable with a one-period lag (Wooldridge 2002, Nijman and Verbeek 1992). This variable indicates which years are missing for each plant. For each year, this variable is 1 if a plant is included in the estimation and 0 otherwise. Thus, the selection indicator models the presence or absence of plants in each year. In all the estimations, the selection indicator was not statistically significant indicating that imbalance in the sample did not lead to bias (Wooldridge 2002). 
The time-invariance of ITIP does not permit estimation of the coefficient of ITIP by the fixed-effects estimation approach (Greene 2003). We therefore use alternative econometric specifications to estimate the coefficient of ITIP. We estimated the Hausman-Taylor (HT) model (Hausman and Taylor 1981) for the random-effects model which overcomes the disadvantage of the need for assuming orthogonality between the random effects and the covariates by fitting a model allowing for correlation between the random effects and the covariates (Greene 2003). The Hausman-Taylor estimator (unlike the fixed-effects estimator) enables estimation of the coefficients of time-invariant independent variables. In our model, it enables estimation of the coefficient of ITIP which is time-invariant. Instrument validity is determined by the HausmanTaylor (HT) specification test p-value. Following Boulding and Christen (2003), we test the sensitivity of results to the use of particular instruments. In the Hausman-Taylor specification, we allow for ITT, ITIP and all control variables to be endogenous i.e. correlated with the disturbances. The insignificance of the HT-Specification test statistic indicates validity of the instruments used for estimation (Greene 2003). The results (not reported here) are robust to other sets of endogenous variables in the Hausman-Taylor specification.

Finally, we estimated the fixed-effects models allowing for the possibility of serial correlation by using the first-order autoregressive (AR1) model $^{6}$. The Baltagi-Wu locally best invariant (LBI) test statistic was 1.96, suggesting that serial correlation is not a serious problem in the data (Baltagi and Wu 1999). Using the AR1 specification, the results are qualitatively unchanged.

\section{RESULTS}

The result of the Productivity regression model is depicted in Table 3. In the fully specified model (Column iv), the coefficients of ITT $\left(\beta_{1}=0.011, \mathrm{p}<0.01\right)$ and ITIP $\left(\beta_{2}=0.023\right.$,

${ }^{6}$ Estimation of the AR1 Models are not reported here. 
$\mathrm{p}<0.01)$ are statistically significant. Consistent with hypothesis H4a, in the fully specified model, we find that the interaction term of ITT and Volatility is negative and statistically significant $\left(\beta_{5}=-0.051, \mathrm{p}<0.01\right)$. Conversely, the interaction term of ITIP and Volatility is positive and significant, rendering support for hypothesis $\mathrm{H} 3 \mathrm{a}\left(\beta_{4}=0.028, \mathrm{p}<0.01\right)$. Consistent with prior research (Childerhouse et al. 2008), demand Volatility has a negative and statistically significant coefficient $\left(\beta_{3}=-0.174, p<0.05\right)$. The results are generally consistent across the model specifications. An F-test of the joint significance of the interaction terms was rejected $(p<0.001)$ indicating that we can reject the null that the interaction terms are jointly zero.

The result of the Inventory regression model is depicted in Table 4 . We see a qualitatively similar pattern of results in this model. We find a negative statistically significant coefficient of ITT $\left(\beta_{1}=-0.01, \mathrm{p}<0.01\right)$ when the full model is specified (Column iv). Consistent with Hypotheses 4b, we find that the interaction term of ITT and Volatility on inventory is positive and statistically significant $\left(\beta_{5}=0.067, \mathrm{p}<0.01\right)$. Additionally, the interaction term of ITIP and Volatility is negative and significant $\left(\beta_{4}=-0.039, \mathrm{p}<0.01\right)$, rendering support for Hypothesis 3b. Consistent with prior research (Childerhouse et al. 2008), demand Volatility has a positive and statistically significant coefficient $\left(\beta_{3}=0.278, \mathrm{p}<0.01\right)$ in line with the argument that plants facing high volatility in demand tend to have higher levels of inventory in order to buffer against volatile demand. The direct effect of ITIP on inventory is not significant in the estimation; therefore $\mathrm{H} 2 \mathrm{~b}$ is not supported. The results are consistent across the model specifications as shown in Table 4. Again, an F-test of the joint significance of the interaction terms was rejected at the $p<0.001$ level of significance indicating that we can reject the null that the interaction terms are jointly zero. 
Taken together, we find strong support for $\mathrm{H} 1, \mathrm{H} 3$ and $\mathrm{H} 4$, whereas $\mathrm{H} 2$ is partially supported. In our estimations, the use of IT for information-based partnerships (ITIP) was significantly associated with productivity but not with inventory turnover.

Table 3: Parameter Estimates (Dependent Variable = Log Labor Productivity)

\begin{tabular}{|c|c|c|c|c|c|c|}
\hline & $\begin{array}{c}\text { Fixed Effects } \\
\text { Model } \\
\text { (i) }\end{array}$ & $\begin{array}{c}\text { Fixed Effects } \\
\text { Model } \\
\text { (ii) }\end{array}$ & $\begin{array}{c}\text { Hausman } \\
\text { Taylor Model } \\
\text { (iii) }\end{array}$ & $\begin{array}{c}\text { Hausman } \\
\text { Taylor Model } \\
\text { (iv) }\end{array}$ & \begin{tabular}{|c|} 
Hausman \\
Taylor Model \\
(v)
\end{tabular} & $\begin{array}{c}\text { Hausman } \\
\text { Taylor Model } \\
\text { (vi) }\end{array}$ \\
\hline$\pi$ & $\begin{array}{r}0.001 \\
(0.002) \\
\end{array}$ & $\begin{array}{c}0.010^{\text {*k2 }} \\
(0.003)\end{array}$ & $\begin{array}{c}0.001 \\
(0.002) \\
\end{array}$ & $\begin{array}{c}0.011^{\text {tzk2 }} \\
(0.002)\end{array}$ & $\begin{array}{c}0.001 \\
(0.002) \\
\end{array}$ & $\begin{array}{c}0.006^{\mathrm{xxx}} \\
(0.002)\end{array}$ \\
\hline ITIP & & & $\begin{array}{c}0.660^{\mathrm{kx}} \\
(0.282)\end{array}$ & $\begin{array}{l}0.023^{\mathrm{x}=\mathrm{z}} \\
(0.005)\end{array}$ & $\begin{array}{c}0.613^{\text {** }} \\
(0.279)\end{array}$ & $\begin{array}{l}0.022^{\text {k.kx }} \\
(0.005)\end{array}$ \\
\hline Volatility & $\begin{array}{l}-0.298^{\text {kixi }} \\
(0.062) \\
\end{array}$ & $\begin{array}{c}-0.184^{\text {x.2x }} \\
(0.076) \\
\end{array}$ & $\begin{array}{c}-0.298^{\text {*xik }} \\
(0.017) \\
\end{array}$ & $\begin{array}{c}0.174^{\text {xax }} \\
(0.027)\end{array}$ & & \\
\hline$\Pi \mathrm{IP} \times$ Volatility & & $\begin{array}{c}0.034^{* *} \\
(0.017)\end{array}$ & & $\begin{array}{l}0.028^{\text {*ax }} \\
(0.007)\end{array}$ & & \\
\hline$\Pi \mathrm{x}$ Volatility & & $\begin{array}{l}-0.060^{\text {*kx }} \\
(0.015)\end{array}$ & & $\begin{array}{l}-0.051^{\text {takx }} \\
(0.006)\end{array}$ & & \\
\hline HIGHVOLATILTY & & & & & $\begin{array}{l}-0.031^{* * \times x} \\
(0.004)\end{array}$ & $\begin{array}{l}-0.023^{\text {tak }} \\
(0.007)\end{array}$ \\
\hline ITT $x$ HIGHVOLATILTY & & & & & & $\begin{array}{l}-0.005^{\text {tak }} \\
(0.002) \\
\end{array}$ \\
\hline ITIP x HIGHVOLATILTYY & & & & & & $\begin{array}{c}0.005^{\text {t* }} \\
(0.002)\end{array}$ \\
\hline Capital Intensity & $\begin{array}{r}0.013^{*} \\
(0.007) \\
\end{array}$ & $\begin{array}{r}0.011 \\
(0.007) \\
\end{array}$ & $\begin{array}{l}0.013^{\text {*x* }} \\
(0.004) \\
\end{array}$ & $\begin{array}{l}0.012^{\text {*x* }} \\
(0.004) \\
\end{array}$ & $\begin{array}{l}0.017^{\text {*x*2 }} \\
(0.004)\end{array}$ & $\begin{array}{c}0.017^{\text {*** }} \\
(0.004) \\
\end{array}$ \\
\hline Material Intensity & $\begin{array}{c}0.398^{\text {*x* }} \\
(0.021) \\
\end{array}$ & $\begin{array}{l}0.393^{\text {*x*2}} \\
(0.021) \\
\end{array}$ & $\begin{array}{l}0.398^{\text {*x* }} \\
(0.006) \\
\end{array}$ & $\begin{array}{l}0.396^{\text {*kx }} \\
(0.006) \\
\end{array}$ & $\begin{array}{l}0.410^{\text {*kx }} \\
(0.006)\end{array}$ & $\begin{array}{c}0.411^{\text {tax }} \\
(0.006)\end{array}$ \\
\hline Energy Intensity & $\begin{array}{c}0.060^{* 2 x} \\
(0.011)\end{array}$ & $\begin{array}{l}0.061^{\text {*x*x }} \\
(0.011) \\
\end{array}$ & $\begin{array}{l}0.060^{\text {*ax }} \\
(0.006) \\
\end{array}$ & $\begin{array}{l}0.062^{\text {k.xz }} \\
(0.006) \\
\end{array}$ & $\begin{array}{l}0.065^{\text {*x: }} \\
(0.006)\end{array}$ & $\begin{array}{c}0.067^{\text {*kx }} \\
(0.006) \\
\end{array}$ \\
\hline Capacity Utilization & $\begin{array}{c}0.167^{\text {*ax }} \\
(0.019)\end{array}$ & $\begin{array}{c}0.166^{\text {*xz }} \\
(0.019) \\
\end{array}$ & $\begin{array}{c}0.167^{\text {tak }} \\
(0.013) \\
\end{array}$ & $\begin{array}{c}0.164^{\text {**x }} \\
(0.013) \\
\end{array}$ & $\begin{array}{l}0.167^{\text {*xz }} \\
(0.013)\end{array}$ & $\begin{array}{c}0.164^{\text {**** }} \\
(0.014)\end{array}$ \\
\hline Size & $\begin{array}{c}-0.223^{\text {**x* }} \\
(0.027) \\
\end{array}$ & $\begin{array}{c}-0.240^{\text {*x* }} \\
(0.027) \\
\end{array}$ & $\begin{array}{c}-0.223^{\text {*ax }} \\
(0.01) \\
\end{array}$ & $\begin{array}{c}-0.229^{\mathrm{xkx}} \\
(0.01)\end{array}$ & $\begin{array}{c}-0.187^{\text {*x*x }} \\
(0.01)\end{array}$ & $\begin{array}{c}-0.181^{\text {tax }} \\
(0.01) \\
\end{array}$ \\
\hline MULTIPLANT firm & $\begin{array}{r}0.005 \\
(0.015) \\
\end{array}$ & $\begin{array}{r}0.007 \\
(0.015) \\
\end{array}$ & $\begin{array}{r}0.005 \\
(0.016) \\
\end{array}$ & $\begin{array}{r}0.001 \\
(0.016) \\
\end{array}$ & $\begin{array}{r}0.002 \\
(0.016) \\
\end{array}$ & $\begin{array}{r}0.001 \\
(0.016) \\
\end{array}$ \\
\hline Plant Age & $\begin{array}{r}-0.000 \\
(0.002) \\
\end{array}$ & $\begin{array}{r}0.000 \\
(0.003) \\
\end{array}$ & $\begin{array}{r}-0.000 \\
(0.006) \\
\end{array}$ & $\begin{array}{c}-0.015^{* x} \\
(0.006) \\
\end{array}$ & $\begin{array}{r}-0.001 \\
(0.006) \\
\end{array}$ & $\begin{array}{r}-0.008 \\
(0.006) \\
\end{array}$ \\
\hline Share of Exports & $\begin{array}{c}-0.015^{* * x} \\
(0.003) \\
\end{array}$ & $\begin{array}{c}-0.015^{\text {**x }} \\
(0.003)\end{array}$ & $\begin{array}{c}-0.015^{* \times *} \\
(0.002)\end{array}$ & $\begin{array}{c}-0.014^{\text {x*x }} \\
(0.002)\end{array}$ & $\begin{array}{c}-0.014^{\mathrm{k} * \mathrm{x}} \\
(0.002)\end{array}$ & $\begin{array}{c}-0.014^{\text {*x*x }} \\
(0.002)\end{array}$ \\
\hline Skill Ratio & $\begin{array}{c}-0.031^{* * *} \\
(0.009) \\
\end{array}$ & $\begin{array}{c}-0.031^{\text {**x }} \\
(0.009)\end{array}$ & $\begin{array}{c}-0.031^{* \mathrm{x*}} \\
(0.007)\end{array}$ & $\begin{array}{c}-0.029^{* * * 8} \\
(0.007)\end{array}$ & $\begin{array}{l}-0.030^{\text {*x* }} \\
(0.007)\end{array}$ & $\begin{array}{l}-0.028^{\text {*xz }} \\
(0.007)\end{array}$ \\
\hline F-statistic & 106.83 & 102.22 & & & & \\
\hline Wald Chi-square & & & 9381.67 & 11215.05 & 9129.91 & 11323.73 \\
\hline Prob $>$ Chi-Sqr & 0.0000 & 0.0000 & 0.0000 & 0.0000 & 0.0000 & 0.0000 \\
\hline R-Square & 0.43 & 0.44 & & & & \\
\hline Plants & 6185 & 6185 & 6185 & 6185 & 6194 & 6194 \\
\hline Plant-year Obs. (N) & 19023 & 19023 & 19023 & 19023 & 19045 & 19045 \\
\hline Endogenous Variables for HT & & & All ind & pendent variab & es excluding in & dustry \\
\hline Hausman Spec. Test p-value & & & 0.98 & 1.00 & 0.98 & 0.99 \\
\hline \multicolumn{7}{|c|}{$\begin{array}{l}\text { Notes: (1) Heteroskedasticity-consistent Standard Errors in parentheses. Significant at }{ }^{*}(\mathrm{p}<0.1),{ }^{* *}(\mathrm{p}<0.05) \text { and } \\
* * 2(\mathrm{p}<0.01) \text { level. (2) Estimates for industry (in } \mathrm{HT} \text { models) and time dummies not shown. ( } 3 \text { ) Results are based on the } 6 \text { - } \\
\text { year panel (1997-2002). Results of the shorter panel }(1999-2002) \text { are consistent with these results. } \\
\text { (4) HT model results are robust to the use of other sets of endogenous variables (Boulding and Christen 2003). }\end{array}$} \\
\hline
\end{tabular}




\begin{tabular}{|c|c|c|c|c|c|c|}
\hline \multicolumn{7}{|c|}{$\begin{array}{c}\text { Table 4: Parameter Estimates } \\
\{\text { Dependent Variable }=\text { Log (Total Inventory/ Total Value of Shipments) }\}\end{array}$} \\
\hline & $\begin{array}{l}\text { Fixed Effects } \\
\text { Model } \\
\text { (i) }\end{array}$ & $\begin{array}{l}\text { Fixed Effects } \\
\text { Model } \\
\text { (ii) }\end{array}$ & \begin{tabular}{c|} 
Hausman \\
Taylor Model \\
(iii)
\end{tabular} & $\begin{array}{c}\text { Hausman } \\
\text { Taylor Model } \\
\text { (iv) }\end{array}$ & \begin{tabular}{|c|} 
Hausman \\
Taylor Model \\
(v)
\end{tabular} & $\begin{array}{l}\text { Hausman } \\
\text { Taylor Model } \\
\text { (vi) }\end{array}$ \\
\hline ITT & \begin{tabular}{c|c|}
0.002 \\
$(0.003)$ \\
\end{tabular} & $\begin{array}{l}-0.010^{* *} \\
(0.004)\end{array}$ & $\begin{array}{r}0.002 \\
(0.002) \\
\end{array}$ & $\begin{array}{l}-0.011^{* * *} \\
(0.003)\end{array}$ & \begin{tabular}{c|c|}
0.001 \\
$(0.002)$ \\
\end{tabular} & $\begin{array}{c}-0.004^{* *} \\
(0.002) \\
\end{array}$ \\
\hline ITIP & & & $\begin{array}{r}-0.097 \\
(0.089)\end{array}$ & $\begin{array}{r}0.003 \\
(0.007) \\
\end{array}$ & $\begin{array}{r}-0.011 \\
(0.076)\end{array}$ & $\begin{array}{r}-0.005 \\
(0.007)\end{array}$ \\
\hline Volatility & $\begin{array}{c}0.407^{\text {*** }} \\
(0.071) \\
\end{array}$ & $\begin{array}{l}0.286^{* * *} \\
(0.094) \\
\end{array}$ & $\begin{array}{l}0.407^{* \times *} \\
(0.022) \\
\end{array}$ & $\begin{array}{l}0.278^{* * *} \\
(0.036) \\
\end{array}$ & & \\
\hline ITIP x Volatility & & $\begin{array}{c}-0.044^{*} \\
(0.025)\end{array}$ & & $\begin{array}{l}-0.039^{* \times *} \\
(0.01)\end{array}$ & & \\
\hline ITT x Volatility & & $\begin{array}{l}0.074^{\text {***x}} \\
(0.023)\end{array}$ & & $\begin{array}{l}0.067^{* * x *} \\
(0.008)\end{array}$ & & \\
\hline HIGHVOLATILITY & & & & & $\begin{array}{l}0.041^{\mathrm{kx*}} \\
(0.006)\end{array}$ & $\begin{array}{c}0.010 \\
(0.01) \\
\end{array}$ \\
\hline ITIP x HIGHVOLATILITY & & & & & & $\begin{array}{l}-0.004^{* *} \\
(0.002)\end{array}$ \\
\hline ITT x HIGHVOLATILITY & & & & & & $\begin{array}{l}0.012^{\text {*x* }} \\
(0.002) \\
\end{array}$ \\
\hline Capital Intensity & $\begin{array}{r}-0.012 \\
(0.011) \\
\end{array}$ & $\begin{array}{r}-0.008 \\
(0.011) \\
\end{array}$ & $\begin{array}{l}-0.012^{* *} \\
(0.006)\end{array}$ & $\begin{array}{r}-0.011 \\
(0.006) \\
\end{array}$ & $\begin{array}{c}-0.016^{* \times *} \\
(0.006) \\
\end{array}$ & $\begin{array}{l}-0.015^{* *} \\
(0.006) \\
\end{array}$ \\
\hline Plant Capacity Utilization & $\begin{array}{c}-0.173^{\text {*** }} \\
(0.029) \\
\end{array}$ & $\begin{array}{l}-0.169^{* * *} \\
(0.029) \\
\end{array}$ & $\begin{array}{l}-0.173^{\text {kx }} \\
(0.019)\end{array}$ & $\begin{array}{l}-0.169^{* \times *} \\
(0.020) \\
\end{array}$ & $\begin{array}{l}-0.179^{* * *} \\
(0.02) \\
\end{array}$ & $\begin{array}{l}-0.169^{\text {*x*}} \\
(0.020)\end{array}$ \\
\hline Size & $\begin{array}{r}-0.016 \\
(0.029) \\
\end{array}$ & $\begin{array}{r}0.002 \\
(0.029) \\
\end{array}$ & $\begin{array}{r}-0.016 \\
(0.013) \\
\end{array}$ & $\begin{array}{r}-0.013 \\
(0.012) \\
\end{array}$ & $\begin{array}{c}-0.063^{* * *} \\
(0.013) \\
\end{array}$ & $\begin{array}{c}-0.059^{\mathrm{x*}} \\
(0.012)\end{array}$ \\
\hline MULTIPLANT firm & $\begin{array}{l}0.075^{\star x *} \\
(0.026)\end{array}$ & $\begin{array}{l}0.076^{* x *} \\
(0.026)\end{array}$ & $\begin{array}{l}0.079^{* * *} \\
(0.021)\end{array}$ & $\begin{array}{l}0.079^{* * *} \\
(0.021)\end{array}$ & $\begin{array}{l}0.081^{* k *} \\
(0.021)\end{array}$ & $\begin{array}{l}0.083^{* x *} \\
(0.022)\end{array}$ \\
\hline F-statistic or Wald Chi- sqr & 11.12 & 12.04 & 827.59 & 1112.69 & 656.6 & 814.88 \\
\hline Prob $>$ F or Prob $>$ Chi-sqr & 0.0000 & 0.0000 & 0.0000 & 0.0000 & 0.0000 & 0.0000 \\
\hline R-Square & 0.0286 & 0.0331 & & & & \\
\hline Plants & 6506 & 6506 & 6506 & 6506 & 6513 & 6513 \\
\hline Plant-year Observations (N) & 21204 & 21204 & 21204 & 21204 & 21241 & 21241 \\
\hline \begin{tabular}{|l|} 
Endogenous variables for \\
Hausman-Taylor (HT) model
\end{tabular} & & & \multicolumn{4}{|c|}{ All independent variables excluding industry } \\
\hline $\begin{array}{l}\text { Hausman Specification } \\
\text { Test p-value }\end{array}$ & & & 1.00 & 0.99 & 1.00 & 0.99 \\
\hline $\begin{array}{l}\text { Notes: (1) Heteroskedasticity- } \\
* * * *(p<0.01) \text { level. (2) Estimate } \\
\text { 6-year panel (1997-2002). Re } \\
\text { Taylor model results are robu }\end{array}$ & $\begin{array}{l}\text {-consistent S } \\
\text { es for industry } \\
\text { sults of the sl } \\
\text { ist to the use }\end{array}$ & $\begin{array}{l}\text { ndard Errors ir } \\
\mathrm{n} \text { HT models) } \\
\text { iter panel ( } 19 \\
\text { other sets of } \mathrm{e}\end{array}$ & $\begin{array}{l}\text { arentheses. S } \\
\text { id time dummi } \\
\text { 2002) are con } \\
\text { logenous varia }\end{array}$ & $\begin{array}{l}\text { ignificant at }{ }^{*}(p \\
\text { es not shown. } \\
\text { sistent with the } \\
\text { bles (Boulding }\end{array}$ & $\begin{array}{l}<0.1),{ }^{* *}(p<0.05 \\
\text { (3) Results are } \\
\text { se results. (4) } \\
\text { and Christen } 2\end{array}$ & $\begin{array}{l}\text { b) and } \\
\text { based on the } \\
\text { Hausman- } \\
003 \text { ). }\end{array}$ \\
\hline
\end{tabular}

The main effect of ITT on business performance is consistent with a large body of literature on the value of IT and e-business in the supply chain (Zhu et al 2005, Dedrick et al. 2003). Our hypotheses ( $\mathrm{H} 3$ and $\mathrm{H} 4)$ of the moderating role of demand volatility in respectively mitigating and reinforcing the value of ITT and ITIP receive strong support in the productivity and inventory models of performance. These results suggest that the value co-created from using 
IT for information-based strategic partnership is stronger as the volatility of demand of the firm increases. Figure $3 \mathrm{a}$ and $3 \mathrm{~b}$ depict these relationships for the Productivity model. As suggested by Carte and Russell (2003) and following Ravichandran et al. (2009), we interpret the main effect and the interaction effect from the estimates of the fully specified model simultaneously by using partial derivatives with respect to ITT and ITIP. Analyzing the productivity estimates from the last two columns of Table 3, we get:

$$
\begin{aligned}
& \partial \text { Productivity } / \partial \mathrm{ITT}=0.006-0.005 \times \text { HIGHVOLATILITY } \\
& \partial \text { Productivity } / \partial \mathrm{ITIP}=0.022+0.005 \times \text { HIGHVOLATILITY }
\end{aligned}
$$

\section{Fig. 3a: Interaction Effect of ITIP with Volatility}

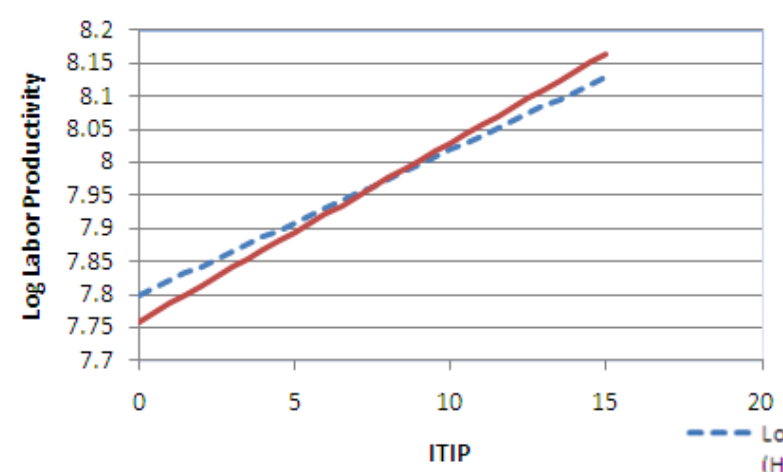

High Volatility
(HIGHVOLATIL

\section{Fig. 3b: Interaction Effect of ITT} with Volatility

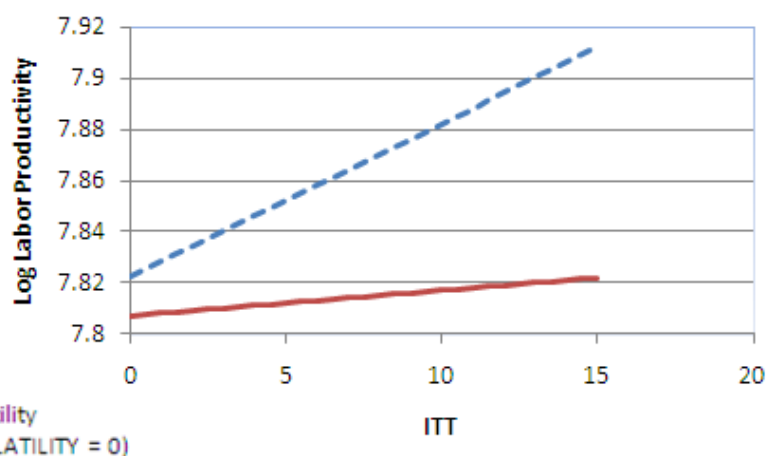

Note: Estimates from columns (v) and (vi) of Table 3 are used to construct these graphs.

Interpreting the coefficients from the fully specified model (Model vi) in Tables 3 and 4, we find that a unit increase in ITT is associated with a $\exp (0.006)$ ie. $0.602 \%$ increase in labor productivity and a $\exp (0.004)$ i.e. $0.401 \%$ decrease in inventory-sales ratio. A unit increase in ITIP is associated with a $\exp (0.022)$ i.e. a $2.2 \%$ increase in labor productivity, though with no significant decrease in inventory. Interestingly, we find that in the Productivity model, the coefficient of ITIP (in the Hausman-Taylor specification) is statistically significantly higher than the coefficient of ITT $(p<0.05)$. Even though the coefficients of ITIP and ITT are not directly comparable, this empirical finding is in some contrast to the theoretical finding of Cachon and 
Fisher (2000) that using IT to expand the flow of information is not as beneficial as using IT to expand the flow of goods through the supply chain.

\section{DISCUSSION}

\subsection{Summary \& Implications}

This paper makes two primary contributions. First, to the best of our knowledge, it is among the few studies that empirically examine the co-created value of information-based integrated partnerships in the supply chain using objective measures of business performance. From a research standpoint, the distinction between transactional IT use and IT for informationbased partnerships is important and has not been the focus of earlier work (Kohli and Grover 2008). The information-based integration capabilities of firms may complement the benefits from implementing pure transaction-oriented technologies and should be seen as another dimension of the firm's ability to co-create value with their supply chain partners. Second, our results show that in high clock-speed environments, though the co-created value of transactional IT may be reduced (Hypothesis 4), the co-created value of IT for information-based integrated partnerships is reinforced (Hypothesis 3). This finding contrasts with an earlier related empirical finding pertaining to the contribution of the breadth of information sharing to supply chain flexibility (Gosain et al. 2005). A potential explanation for the apparently contrasting findings is that the phenomena being studied, though related, are different. We use objective measures of co-created value in the focal plant, whereas Gosain et al. (2005) used a survey-based perceptual measure of the flexibility of a particular partnership.

The empirical evidence of the enhancement of the value of information-based integrated partnerships under volatile demand conditions complements the related analytical research in this area which found contrasting results of the value of information sharing under volatile 
conditions. While some prior analytical studies found the value of information sharing to be enhanced in volatile conditions (e.g. Lee et al. 2000), others found it to be reduced (e.g. Chen 1998, pg. S233). This study provides empirical evidence for the enhanced value of informationbased partnerships in volatile conditions using two objective measures of performance. By investigating the moderating role of demand volatility, this study takes a step towards addressing the call of Rai et al. (2006, pg. 239) for the need to examine the "role of information flow integration and inter-organizational relational capabilities" on firm performance in "business environments characterized by different demand patterns". By examining the implications of a high clockspeed environment on co-created value in the supply chain, our research begins to address their (Rai et al. 2006) call to examine strategic choices in the supply chain in uncertain demand conditions. This study is also in accord with recommendations (Sahin and Robinson 2002) for more research into the value of information sharing in the supply chain.

From a practical standpoint, our results suggest that it would be worthwhile for firms to invest more in integrated information-based partnerships using IT with customers and suppliers to assuage the negative effects of variability in demand by building an agile supply chain based on a culture of trust between the firm and its partners (Christopher 2000). Demand volatility has an inverse relationship with financial and operational performance and IT-based information partnerships provides firms with mechanisms to co-create value and mitigate the detrimental impact of variability on performance. To assuage the negative effects of demand volatility, supply chain partners should transition from transaction-oriented IT usage to collaborative information-based integrated partnerships. Firms in high clockspeed industries must thus pay more attention to using IT for information-based partnerships with their supply chain partners since they are more likely to pay off. Our results suggest that an information-driven supply chain 
may enable firms to predict market requirements and adapt in the face of volatile market conditions.

To remain competitive, manufacturers must restructure their global supply chains to achieve greater flexibility, efficiency, and agility. For manufacturing-specific lines of business, executives must collaborate with suppliers and customers to co-create value. By using IT with a strategic and partnership focus, firms can confront the challenges of volatile demand, adapt to and capitalize on change. Using IT for integrated partnerships can provide the agility and flexibility for improved business and operational performance in response to changing demand conditions, enabling firms to more efficiently manage the value chain. This study shows the importance of the role of IT for collaborative purposes in co-creating value in the supply chain. An information-driven approach ensures that adaptive capabilities are built into the supply chain so that it becomes more agile, with greater value for all parties to partake of (Kohli and Grover 2008).

\subsection{Limitations and Future Research}

There are some limitations in this study that serve as a starting point for future research. First, since we use data only from respondents and do not adjust for non-respondents to the CNUS, the results of this study may apply only to responding plants. Additionally, the sample consists of only surviving plants. Little can be said about plants that had closed during or prior to the period of the study. Second, though the panel dataset is relatively short, our method of construction (although used in prior research) of the panel dataset to make optimal use of the available data might be considered a limitation. Third, our binary measures of IT are based on usage, which is a benefit in that we capture IT in use rather than the mere presence of IT, but a potential limitation since we do not have a more granular metric for the extent of usage (Devaraj 
and Kohli 2003). Our binary metrics of usage might be viewed as a reliable proxy for such a measure, subject to confirmation by future research. Although many prior IT value studies have employed binary measures of usage of IT, future research can use more refined measures of usage of transactional technology and information sharing. Fourth, our measure of volatility is on an annual basis. Future studies will benefit by employing a more fine-grained measure based on a shorter timeframe, for example weekly or monthly. Finally, our measure of volatility may partially be a result of internal decisions, actions and process efficiency rather than changes in customer demand preferences.

There are several useful directions for further research. First, the causal mechanisms of the moderating role of demand side volatility on IT for information-based partnerships and transaction IT need to be examined. Future research can look at more complex interrelations and can use alternative methods (such as structural equation modeling) or case studies to examine the driving factors behind the differential impact of volatility on the value of IT. Second, though this paper studied the moderating role of demand volatility on the co-creation of value through IT, future research can investigate the value of information-based partnership under conditions of supply volatility (Rai et al. 2006). Future research can also study the contextual impact of information sharing on other measures of performance such as innovation. Third, future research can empirically examine whether the business performance effects of IT for information-based partnerships and transactions are different when the IT under consideration is with upstream and downstream partners in the supply chain. Finally, our study context is limited to the U.S. manufacturing sector. Although this enhances the internal validity of the analysis, it may limit the generalizability of our findings. Extending this study to other settings and examining whether 
the results hold in other national environments, particularly in less developed countries, may be

an interesting line of inquiry.

\section{Appendix}

\begin{tabular}{|c|c|c|c|c|c|c|c|}
\hline \multicolumn{8}{|c|}{ Appendix A: Distribution of Manufacturing Plants in Sample by NAIC S code ${ }^{\#}$} \\
\hline \multirow[b]{2}{*}{$\begin{array}{l}\text { 3-digit } \\
\text { NAICS } \\
\text { code } \\
\end{array}$} & \multirow[b]{2}{*}{ Industry } & \multicolumn{2}{|c|}{\begin{tabular}{|c|}
$\begin{array}{c}\text { Statistical Abstract of the } \\
\text { U.S. * }\end{array}$ \\
\end{tabular}} & \multicolumn{2}{|c|}{ Productivity Model } & \multicolumn{2}{|c|}{ Inventory Model } \\
\hline & & $\begin{array}{l}\text { \# of } \\
\text { Plants } \\
\text { in } 2000\end{array}$ & $\begin{array}{c}\% \text { of U.S. } \\
\text { Manufacturers }\end{array}$ & $\begin{array}{l}\text { \# of Plants } \\
\text { in Sample } \\
\text { in } 2000\end{array}$ & $\mid \begin{array}{l}\% \text { of } \\
\text { Sample }\end{array}$ & $\begin{array}{l}\text { \# of Plants } \\
\text { in Sample } \\
\text { in } 2000\end{array}$ & $\begin{array}{l}\% \text { of } \\
\text { Sample }\end{array}$ \\
\hline 311 & Food Manufacturing & 26401 & 7.45 & 484 & 8.35 & 253 & 6.53 \\
\hline 312 & Beverage and Tobacco Product Manufacturing & 2869 & 0.81 & 69 & 1.19 & 38 & 0.98 \\
\hline 313 & Textile Mills & 4449 & 1.26 & 116 & 2.00 & 82 & 2.12 \\
\hline 314 & Textile Product Mills & 6881 & 1.94 & 52 & 0.90 & 43 & 1.11 \\
\hline 315 & Apparel Manufacturing & 16505 & 4.66 & 112 & 1.93 & 75 & 1.94 \\
\hline 316 & Leather and Allied Product Manufacturing & 1783 & 0.50 & 37 & 0.64 & 33 & 0.85 \\
\hline 321 & Wood Product Manufacturing & 17328 & 4.89 & 164 & 2.83 & 104 & 2.69 \\
\hline 322 & Paper Manufacturing & 5790 & 1.63 & 181 & 3.12 & 146 & 3.77 \\
\hline 323 & Printing and Related Support Activities & 39035 & 11.01 & 89 & 1.54 & 41 & 1.06 \\
\hline 324 & Petroleum and Coal Products Manufacturing & 2210 & 0.62 & 69 & 1.19 & 30 & 0.77 \\
\hline 325 & Chemical Manufacturing & 13426 & 3.79 & 352 & 6.07 & 211 & 5.45 \\
\hline 326 & Plastics and Rubber Products Manufacturing & 16292 & 4.60 & 227 & 3.92 & 158 & 4.08 \\
\hline 327 & Nonmetallic Mineral Product Manufacturing & 16537 & 4.66 & 211 & 3.64 & 151 & 3.90 \\
\hline 331 & Primary Metal Manufacturing & 6300 & 1.78 & 353 & 6.09 & 226 & 5.84 \\
\hline 332 & Fabricated Metal Product Manufacturing & 61144 & 17.25 & 839 & 14.47 & 546 & 14.10 \\
\hline 333 & Machinery Manufacturing & 29442 & 8.31 & 743 & 12.82 & 519 & 13.40 \\
\hline 334 & Computer and Electronic Product Manufacturing & 17148 & 4.84 & 435 & 7.50 & 314 & 8.11 \\
\hline 335 & $\begin{array}{l}\text { Electrical Equipment, Appliance, and } \\
\text { Component Manufacturing }\end{array}$ & 7041 & 1.99 & 380 & 6.56 & 278 & 7.18 \\
\hline 336 & Transportation Equipment Manufacturing & 12766 & 3.60 & 557 & 9.61 & 354 & 9.14 \\
\hline 337 & Furniture and Related Product Manufacturing & 19848 & 5.60 & 111 & 1.91 & 94 & 2.43 \\
\hline 339 & Miscellaneous Manufacturing & 31303 & 8.83 & 216 & 3.73 & 176 & 4.55 \\
\hline & TOTAL & 354498 & 100 & 5797 & 100 & 3872 & 100 \\
\hline
\end{tabular}

\begin{tabular}{|l|l|c|c|c|c|c|c|c|c|c|c|c|}
\hline \multicolumn{10}{|c|}{ Appendix B: Descriptive Statistics and Correlations for Inventory Model } \\
\hline \multicolumn{1}{|c|}{ Variables } & N & Mean & SD & $\mathbf{1}$ & $\mathbf{2}$ & $\mathbf{3}$ & $\mathbf{4}$ & $\mathbf{5}$ & $\mathbf{6}$ & $\mathbf{7}$ & $\mathbf{8}$ \\
\hline $\mathbf{1}$ & INV & 23734 & -2.24 & 0.81 & 1 & & & & & & & \\
\hline $\mathbf{2}$ & ITT & 21251 & 3.07 & 2.45 & 0.00 & 1 & & & & & & \\
\hline $\mathbf{3}$ & ITIP & 23734 & 1.95 & 2.29 & 0.02 & $0.41^{*}$ & 1 & & & & & \\
\hline $\mathbf{4}$ & Volatility & 23676 & 0.15 & 0.15 & $0.08^{*}$ & $0.03^{*}$ & 0.01 & 1 & & & & \\
\hline $\mathbf{5}$ & Capital & 23718 & 4.3 & 1.08 & $-0.09^{*}$ & $0.06^{*}$ & $-0.02^{*}$ & -0.01 & 1 & & & \\
\hline $\mathbf{6}$ & Capacity Utilization & 23734 & 0.73 & 0.20 & $-0.14^{*}$ & $-0.09^{*}$ & $-0.06^{*}$ & $-0.12^{*}$ & $0.09^{*}$ & 1 & & \\
\hline $\mathbf{7}$ & Size & 23734 & 5.83 & 0.99 & $-0.07^{*}$ & $0.12^{*}$ & $0.18^{*}$ & $-0.08^{*}$ & $0.04^{*}$ & $0.16^{*}$ & 1 & \\
\hline $\mathbf{8}$ & MULTIPLANT & 23734 & 0.94 & 0.23 & -0.01 & $0.09^{*}$ & 0.02 & 0.01 & $0.15^{*}$ & 0.00 & $0.13^{*}$ & 1 \\
\hline * indicates significance at $\alpha=0.01$ & \multicolumn{10}{|c|}{0.00} \\
\hline
\end{tabular}




\section{APPENDIX C: Detailed Variable Descriptions}

\begin{tabular}{|l|l|}
\hline \multicolumn{1}{|c|}{ Variable } & \multicolumn{1}{|c|}{ Opable C1: Computation of non-IT Variables } \\
\hline Labor Productivity & $\log$ (Total Value of Shipments/Number of Employees) \\
\hline Total Inventory & Sum of Raw Materials Inventory, Work-in-process Inventory and Finished-Goods Inventory \\
\hline Inventory-Sales Ratio & $\log$ (Total Inventory /Total Value of Shipments) \\
\hline Capacity Utilization & Ratio of Actual Production to Full Production Capability. \\
\hline Age of Plant & Number of years since first appearance in Longitudinal Business Database \\
\hline Material Intensity & $\log$ (Value of Materials used / Number of Employees) \\
\hline Capital Intensity & $\log$ (Book Value of Capital / Number of Employees) \\
\hline Energy Intensity & $\log$ (Value of Energy used / Number of Employees) \\
\hline Skill Mix & $\log$ (Number of non-production workers / Number of Production workers) \\
\hline Volatility & Standard Deviation of the Iog of (total value of shipments) over the previous five years \\
\hline Share of Exports & $\log$ (Value of Exports /Total Value of Shipments) \\
\hline Size of Plant & $\log$ (Number of Employees) \\
\hline Multi-plant firm & 1 if plant is part of a multi-plant firm; 0 otherwise \\
\hline $\begin{array}{l}\text { Notes: (1) Total Value of Shipments, Value of Materials, Value of Energy and Inventory are deflated to 1997 prices } \\
\text { using (6-digit NAICS) industry-level price indices obtained from the U.S. Census Bureau. } \\
\text { (2) Results robust to alternative measures of Volatility as described in Section 4.2. } \\
\text { (3) Results robust to alternative measures of Size (e.g. Total Worker hours). }\end{array}$ \\
\hline
\end{tabular}

\begin{tabular}{|c|c|c|c|}
\hline \multicolumn{4}{|c|}{ Table C2: IT Variables } \\
\hline Construct & Variable & Operationalization/Computation & Measures \\
\hline $\begin{array}{l}\text { IT for } \\
\text { Transactions }\end{array}$ & ITT & Count of transactional IT measures & $\begin{array}{l}\text { IT for: } \\
\text { - Payment to Vendors } \\
\text { - Ordering from Vendors } \\
\text { - Using Electronic Marketplaces } \\
\text { - Ordering by customers } \\
\text { - Payment by Customers } \\
\text { - Customer Support } \\
\text { - Online Bidding }\end{array}$ \\
\hline $\begin{array}{c}\text { IT for } \\
\text { Information- } \\
\text { based } \\
\text { Partnership }\end{array}$ & ITIP & $\begin{array}{c}\text { Count of Information sharing measures } \\
\text { enabled by IT }\end{array}$ & $\begin{array}{l}\text { Online information sharing of the following } \\
\text { with customers and suppliers: } \\
\text { - Design Specifications } \\
\text { - Demand projections } \\
\text { - Inventory Data } \\
\text { - Production Schedules }\end{array}$ \\
\hline
\end{tabular}




\section{References}

Amit, R., and C. Zott. 2001. Value creation in E-business. Strat. Management Journal 22, (6).

Atrostic, B.K., and S. Nguyen. 2005. IT and productivity in U.S. manufacturing: Do computer networks matter? Economic Inquiry 43, (3): 493-506.

Baltagi, B., and P. Wu. 1999. Unequally spaced panel data regressions with AR(1) disturbances. Econometric Theory 15, (6): 814.

Banker, R., I. Bardhan, H. Chang, and S. Lin. 2006. Plant information systems, manufacturing capabilities, and plant performance. MIS Quarterly 30, (2).

Bansak, C., N. Morin, and M. Starr. 2007. Technology, capital spending, and capacity utilization. Economic Inquiry 45, (3).

Barney, J. 1991. Firm resources and sustained competitive advantage. J. of Management 17, (1).

Barua, A., P. Konana, A. Whinston, and F. Yin. 2004. An empirical investigation of net-enabled business value. MIS Quarterly 28, (4).

Berman, Eli, J. Bound, and Z. Griliches. 1994. The Quarterly Journal of Economics 109, .

Bharadwaj, Sundar, Anandhi Bharadwaj, and Elliot Bendoly. 2007. The performance effects of complementarities between information systems, marketing, manufacturing, and supply chain processes. Information Systems Research 18, (4): 437.

Black, S., and L. Lynch. 2001. How to compete: The impact of workplace practices and information technology on productivity. Review of Economics and Statistics 83, (3): 434.

Boone, T., R. Ganeshan, and A. Stenger. 2002. The benefits of information sharing in a supply chain: An exploratory simulation study. In Supply chain management: Models, applications, and research directions., ed. J. Geunes et al.

Boulding, W., and M. Christen. 2003. Sustainable pioneering advantage? profit implications of market entry order. Marketing Science 22, (3): 371.

Bourgeois, L. J., and K. M. Eisenhardt. 1988. Strategic decision-processes in high-velocity environments - 4 cases in the microcomputer industry. Management Science 34, (7).

Bourland, Karla E., Stephen G. Powell, and David F. Pyke. 1996. Exploiting timely demand information to reduce inventories. European Journal of Operational Research 92, (2).

Breusch, T. S., and A. R. Pagan. 1980. The lagrange multiplier test and its applications to modelspecification in econometrics. The Review of Economic Studies 47, (1). 
Brynjolfsson, E., L. Hitt, and A. Saunders. 2007. Information technology and organizational capital. Paper presented at Workshop on Information Systems and Economics, Montreal.

Business Week. J.D. edwards frees up herlitz's shelf space. 2009Available from http://www.businessweek.com/adsections/chain/2.1/jdedwards.html.

Cachon, G. P., and M. Fisher. 2000. Supply chain inventory management and the value of shared information. Management Science 46, (8).

Cachon, Gerard P., and Martin A. Lariviere. 2001. Contracting to assure supply: How to share demand forecasts in a supply chain. Management Science 47, (5).

Carte, T., and C. Russell. 2003. In pursuit of moderation: Nine common errors and their solutions1. MIS Quarterly 27, (3): 479.

Chen, Fangruo. 1998. Echelon reorder points, installation reorder points, and the value of centralized demand information. Management Science 44, (12).

Childerhouse, P., S. Disney, and D. Towill. 2008. On the impact of order volatility in the european automotive sector. International Journal of Production Economics 114, (1): 2.

Christopher, M. 2000. The agile supply chain: Competing in volatile markets. Industrial Marketing Management 29, (1): 37.

Clemons, Eric K., and Row. 1993. Limits to interfirm coordination through information technology: Results of a field study in consumer packaged goods distribution. Journal of Management Information Systems 10, (1).

Crowe, T. 1992. Integration is not synonymous with flexibility. International Journal of Operations Production Management 12, (10): 26.

Daft, R. H., and R. L. Lengel. 1986. Organizational information requirements, media richness and structural design.

David, J., Y. Hwang, B. Pei, and J. Reneau. 2002. The performance effects of congruence between product competitive strategies and purchasing management design. Management Science 48, (7): 866.

Davila, T., Gupta, M. and R. Palmer. 2002. Moving Procurement Systems to the Internet: The Adoption and Use of E-Procurement Technology Models. Stanford GSB Research Paper No. 1742. Available at SSRN: http://ssrn.com/abstract=323923

Dedrick, J., and K. Kraemer. 2005. The impacts of IT on firm and industry structure: The personal computer industry. California Management Review 47, (3): 122. 
Dedrick, J., V. Gurbaxani, and K. Kraemer. 2003. Information technology and economic performance: A critical review of the empirical evidence. ACM Computing Surveys 35, (1).

Dehning, B., V.J. Richardson and R. W. Zmud. 2007. "The Financial Performance Effects of ITBased Supply Chain Management Systems in Manufacturing Firms," Journal of Operations Management 25 (June): 806-824.

Devaraj, S., and R. Kohli. 2003. Performance impacts of information technology: Is actual usage the missing link? Management Science 49, (3): 273.

Dewan, S., C. Shi, and V. Gurbaxani. 2007.Investigating the Risk-Return Relationship of Information Technology Investment. Management Science 53(12), pp. 1829-1842.

Diamantopoulos, A., and H. Winklhofer. 2001. Index construction with formative indicators: An alternative to scale development. J. Marketing Res. 38, (2).

Doms, M., T. Dunne, and K. Troske. 1997. Workers, wages, and technology. The Quarterly Journal of Economics 112, (1).

Dong, S., S. Xu, and K. Zhu. 2009. Information technology in supply chains: The value of ITenabled resources under competition. Information Systems Research 20, (1): 18.

Dunne, T. 1994. Plant age and technology use in U.S. manufacturing industries. The Rand Journal of Economics 25, (3).

Dyer, J., and H. Singh. 1998. The relational view: Cooperative strategy and sources of interorganizational competitive advantage. Academy of Management Review 23, (4): 660.

Eisenhardt, K. M., and J. A. Martin. 2000. Dynamic capabilities: What are they? Strategic Management Journal 21, (10).

Fine, C. 2000. Clockspeed-based strategies for supply chain design. Production and Operations Management 9, (3): 213.

Frohlich, M., and R. Westbrook. 2001. Arcs of integration: An international study of supply chain strategies. Journal of Operations Management 19, (2).

Gattorna, John. 1998. Strategic supply chain alignment. Aldershot, Hampshire, England: Gower.

Gavirneni, S., R. Kapuscinski, and S. Tayur. 1999. Value of information in capacitated supply chains. Management Science 45, (1): 16-24.

Germain, R., C. Claycomb, and D. Cornelia. 2008. Supply chain variability, organizational structure, and performance: The moderating effect of demand unpredictability. Journal of Operations Management 26, (5): 557. 
Gosain, S., A. Malhotra, and O. Sawy. 2005. Coordinating for flexibility in e-business supply chains. Journal of Management Information Systems JMIS 21, (3): 7.

Greenan, N., and J. Mairesse. 2001. Information technology and research and development impacts on productivity and skills: Looking for correlations on french firm level data. NBER Working Paper Series(8075).

Greene, William H. 2003. Econometric analysis. Upper Saddle River, NJ: Prentice Hall.

Gurbaxani, V., and S. Whang. 1991. The impact of information systems on organizations and markets. Communications of the ACM 34, (1): 59.

Hausman, J. and W. Taylor. 1981. Panel data and unobservable individual effects. Econometrica $49,(6)$.

Holweg, M. 2005. The three dimensions of responsiveness. International Journal of Operations Production Management 25, (7/8): 603.

Jarvis, C., S. MacKenzie, and P. Podsakoff. 2003. A critical review of construct indicators and measurement model misspecification in marketing and consumer research. J. Consumer Res. 30, (2): 199.

Jensen, J., R. McGuckin, and K. Stiroh. 2001. The impact of vintage and survival on productivity: Evidence from cohorts of U.S. manufacturing plants. The Review of Economics and Statistics 83, (2).

Katila, R., and S. Shane. 2005. When does lack of resources make new firms innovate? Academy of Management Journal 48, (5): 814.

Kiang, M., and T. S. Raghu. 2000. Marketing on the internet--who can benefit from an online marketing approach? Decision Support Systems 27, (4).

Kobelsky, K., S. Hunter, and V.J. Richardson. 2008. Volatility and Dispersion of Earnings following IT Expenditures," International Journal of Accounting Information Systems, 9 (3 September):157-174.

Kohli, R., and V. Grover. 2008. Business value of IT: An essay on expanding research directions to keep up with the times *. Journal of the Association for Information Systems 9, (1).

Kulp, S., H. Lee, and E. Ofek. 2004. Manufacturer benefits from information integration with retail customers. Management Science 50, (4).

Lee, H. L., K. So, and C. Tang. 2000. The value of information sharing in a two-level supply chain. Management Science 46, (5). 
Lee, H., Padmanabhan V, and Whang S. 2004. Information distortion in a supply chain: The bullwhip effect. Management Science 50, (12):.

Lee, H., and S. Whang. 2000. Information sharing in a supply chain. International Journal of Technology Management 20, (3).

Li, G., H. Yan, S. Wang, and Y. Xia. 2005. Comparative analysis on value of information sharing in supply chains. Supply Chain Management 10, (1): 34.

Li, J., R. Sikora, M. Shaw, and G. Tan. 2006. A strategic analysis of inter organizational information sharing. Decision Support Systems 42, (1): 251.

Lind, M., and R. Zmud. 1995. Improving interorganizational effectiveness through voice mail facilitation of peer-to peer relationships. Organization Science 6, (4): 445.

Lucas, R. E. 1978. Size distribution of business firms. Bell Journal of Economics 9, (2).

Luque, A. 2002. An option-value approach to technology adoption in U.S. manufacturing: Evidence from microdata. Economics of Innovation and New Technology 11, (6): 543.

Malhotra, A., S. Gosain, and O. Sawy. 2007. Leveraging standard electronic business interfaces to enable adaptive supply chain partnerships. Information Systems Research 18, (3): 260.

McGuckin, R., and S. Nguyen. 1995. On productivity and plant ownership change: New evidence from the longitudinal research database. The Rand Journal of Economics 26, (2).

McGuckin, Robert H., and K. Stiroh. 1998. Computers can accelerate productivity growth. Issues in Science and Technology 14, (4).

Melville, N., V. Gurbaxani, and K. Kraemer. 2007. The productivity impact of information technology across competitive regimes: The role of industry concentration and dynamism. Decision Support Systems 43, (1).

Melville, N., K. Kraemer, and V. Gurbaxani. 2004. Review: Information technology and organizational performance: An integrative model of IT business value. MIS Quart. 28, (2).

Milgrom, P., and J. Roberts. 1988. Communication and inventory as substitutes in organizing production. The Scandinavian Journal of Economics 90, (3).

Miller, D., and J. Shamsie. 1996. The resource-based view of the firm in two environments: The hollywood film studios from 1936 to 1965. Academy of Management Journal 39, (3): 519.

Moenaert, Rudy K., and William E. Souder. 1996. Context and antecedents of information utility at the R D/Marketing interface. Management Science 42, (11). 
Mukhopadhyay, T., S. Kekre, and S. Kalathur. 1995. "Business value of information technology: A study of electronic data interchange". MIS Quarterly 19, (2).

Nijman, T., and M. Verbeek. 1992. Nonresponse in panel data: The impact on estimates of a life cycle consumption function. Journal of Applied Econometrics 7, (3): 243.

Pavlou, P., and O. Sawy. 2006. From IT leveraging competence to competitive advantage in turbulent environments: The case of new product development. Inform. Systems Res. 17, (3).

Raghunathan, S. 2003. Impact of demand correlation on the value of and incentives for information sharing in a supply chain. European Journal of Operational Research 146, (3): 634.

Raghunathan, S.. 2001. Information sharing in a supply chain: A note on its value when demand is nonstationary. Management Science 47, (4).

Rai, A., R. Patnayakuni, and N. Seth. 2006. Firm performance impacts of digitally enabled supply chain integration capabilities. MIS Quarterly 30, (2).

Ravichandran, T., S. Han, and I. Hasan. 2009. Diversification and firm performance: Exploring the moderating effects of Information Technology spending. Journal of Management Information Systems 25, (4): 205-240.

Sabath, Robert E., and J. Fontanella. 2002. The unfulfilled promise of supply chain collaboration. Supply Chain Management Review 6, (4).

Sahin, F., and E. Robinson. 2002. Flow coordination and information sharing in supply chains: Review, implications, and directions for future research. Decision Sciences 33, (4): 505.

Sanders, Nada R. 2007. The benefits of using E-business technology: The supplier perspective. Journal of Business Logistics 28, (2).

Saraf, N., C. Langdon and S. Gosain. 2007. IS application capabilities and relational value in interfirm partnerships. Information Systems Research 18, (3): 320.

Schouten, F., M. Eijs, and R. Heuts. 1994. The value of supplier information to improve management of a retailer's inventory. Decision Sciences 25, (1): 1.

Setia, P., V. Sambamurthy, and D. Closs. 2008. Realizing business value of agile IT applications: Antecedents in the supply chain networks. Information Technology and Management. 9, (1): 5 .

Shapiro, C., and H. Varian. 1999. Information rules: A strategic guide to the network economy. Harvard University Press. 
Spekman, R., J. Kamauff, and N. Myhr. 1998. An empirical investigation into supply chain management A perspective on partnerships. International Journal of Physical Distribution Logistics Management 28, (8): 630.

Srinivasan, K., S. Kekre, and T. Mukhopadhyay. 1994. Impact of Electronic Data Interchange Technology on JIT Shipments. Management Science 40, (10) : 1291-1304.

Straub, D., A. Rai, and R. Klein. 2004. Measuring firm performance at the network level: A nomology of the business impact of digital supply networks. J. of Mgt Inform. Sys. 21, (1)

Steckel, J., S. Gupta, and A. Banerji. 2004. Supply chain decision making: Will shorter cycle times and shared point-of-sale information necessarily help? Mgt. Science 50, (4): 458.

Subramani, M. 2004. How do suppliers benefit from information technology use in supply chain relationships? MIS Quarterly 28, (1): 45.

Subramaniam, C., and M. Shaw. 2002. A Study of the value of B2B E-Commerce: The case of Web-based Procurement. International Journal of Electronic Commerce 6, (4): 19-40.

SupplyChainBrain, 2006. Procter \& Gamble use consumer demand info to drive supply network. in Keller Publishing, LLC [database online]. [cited 10/10 2009]. Available from http://www. supplychainbrain.com/content/nc/industry-verticals/cpg/single-articlepage/article/procter-gamble-uses-consumer-demand-info-to-drive-supply-network/.

Tan, B. 2002. Manufacturing risks by using capacity options. Journal of Operational Research Society 53, (2): 232-242.

Teece, D., G. Pisano, and A. Shuen. 1997. Dynamic capabilities and strategic management. Strategic Management Journal 18, (7).

Thomas, 1997. Logistics Plus Agility Equals "Logility". in Thomas Publishing Company.[cited 10/10 2009]. Available from http://www. managingautomation.com/maonline/news/read/Logistics_Plus_Agility_Equa Is_quotLogilityquot_15320.

Treville, S., R. Shapiro, and A. Hameri. 2004. From supply chain to demand chain: The role of lead time reduction in improving demand chain performance. Journal of Operations Management 21, (6).

Wade, M., and J. Hulland. 2004. Review: The resource-based view and information systems research: Review, extension, and suggestions for future research. MIS Quarterly 28, (1).

Wagner, Joachim. 2002. The causal effects of exports on firm size and labor productivity: First evidence from a matching approach. Economics Letters 77, (2) (10): 287-92.

Waller, M., M.E. Johnson and T. Davis. 1999. Vendor-managed inventory in the retail supply chain. Journal of Business Logistics 20, 1, 183-203. 
Weill, P. 1992. The relationship between investment in information technology and firm performance : A study of the valve manufacturing sector. Information Systems Research 3, (4): 307-333.

White, H. 1980. A heteroskedasticity-consistent covariance matrix estimator and a direct test for heteroskedasticity. Econometrica 48, (4): 817.

Wooldridge, J. M. 2002. Econometric analysis of cross section and panel data. Cambridge, MA.

Zhu, K. 2004a. The complementarity of information technology infrastructure and E-commerce capability: A resource-based assessment of their business value. J. of Management Information Systems 21, (1): 167.

Zhu, K. 2004b. Information transparency of business-to-business electronic markets: A gametheoretic analysis. Management Science 50, (5): 670.

Zhu, K., and K. Kraemer. 2005. Post-adoption variations in usage and value of E-business by organizations: Cross-country evidence from the retail industry. Information Systems Research 16, (1)

Zuboff, S. 1988. "In the age of the smart machine: The future of work and power". New York: Basic Books. 